\title{
Potential Effects of Oil and Natural Gas Development on Mule Deer (Odocoileus hemionus) Survival and Fawn Rearing Resource Selection
}

Brett P. Skelly

Follow this and additional works at: https://researchrepository.wvu.edu/etd

\section{Recommended Citation}

Skelly, Brett P., "Potential Effects of Oil and Natural Gas Development on Mule Deer (Odocoileus hemionus) Survival and Fawn Rearing Resource Selection" (2018). Graduate Theses, Dissertations, and Problem Reports. 6654.

https://researchrepository.wvu.edu/etd/6654

This Thesis is protected by copyright and/or related rights. It has been brought to you by the The Research Repository @WVU with permission from the rights-holder(s). You are free to use this Thesis in any way that is permitted by the copyright and related rights legislation that applies to your use. For other uses you must obtain permission from the rights-holder(s) directly, unless additional rights are indicated by a Creative Commons license in the record and/ or on the work itself. This Thesis has been accepted for inclusion in WVU Graduate Theses, Dissertations, and Problem Reports collection by an authorized administrator of The Research Repository @ WVU. For more information, please contact researchrepository@mail.wvu.edu. 


\title{
POTENTIAL EFFECTS OF OIL AND NATURAL GAS DEVELOPMENT ON MULE DEER (Odocoileus hemionus) SURVIVAL AND FAWN REARING RESOURCE SELECTION
}

\author{
Brett P. Skelly \\ Thesis submitted to the School of Natural Resources \\ at West Virginia University \\ in partial fulfillment of the requirements for the degree of \\ Master of Science \\ in \\ Wildlife and Fisheries Management
}

\author{
Christopher T. Rota PhD, Chair \\ Joshua J. Millspaugh PhD, \\ John W. Edwards PhD
}

Division of Forestry and Natural Resources

\author{
Morgantown, West Virginia
}

2018

Keywords: Global Positioning Systems [GPS], mule deer, North Dakota, Montana, Odocoileus hemionus, Resource Selection, Survival

Copyright 2018 Brett P. Skelly 


\section{Abstract \\ POTENTIAL EFFECTS OF OIL AND NATURAL GAS DEVELOPMENT ON MULE DEER (Odocoileus hemionus) SURVIVAL AND FAWN REARING RESOURCE SELECTION}

\section{Brett P. Skelly}

A worldwide increasing demand for both renewable and non-renewable energy resources has been ongoing for the past 50 years and is projected to continually increase for the next two decades. The direct and indirect effects of oil and natural gas development are not quantified but may be playing an important role in mule deer population dynamics. For this project I: (1) evaluated the potential effects of oil and natural gas development on survival probabilities of mule deer and; (2) evaluated the potential effects of oil and natural gas development on fawn rearing resource selection. I assessed mule deer survival and rearing resource selection by evaluating 268 global positioning system (GPS) radio-collars that were deployed from 2012 to 2016. Survival probability was evaluated using known-fate models. Survival covariates included proximity to oil and natural gas development, density of actively drilling wells, road density, minimum temperature, normalized difference vegetation index (NDVI), and age. Rearing resource selection was evaluated using discrete choice analysis. The rearing resource covariates included distance to oil and natural gas development, distance to road, elevation, terrain ruggedness, slope, distance to water resources, and forage availability. I found that distance to nearest active drilling rig had a weak negative effect on mule deer survival probability. I also found that mule deer rearing resource selection was moderately related to distance from an active drilling rig. Determining the potential effects that oil and natural development have on mule deer survival and rearing resource selection can help inform managers on ways to mitigate potential adverse effects. 


\section{DEDICATION}

I wish to dedicate this thesis to my family and friends. 


\section{ACKNOWLEDGMENTS}

This research was supported by North Dakota Game and Fish (Contract No. G025-055);

Montana Fish, Wildlife, and Parks; the North Dakota Industrial Commission; the North Dakota

Oil and Gas Research Program; the North Dakota Petroleum Council; the Montana Department of Natural Resources Reclamation and Development Grants Program, the Bureau of Land

Management; the Mule Deer Foundation; and the West Virginia University Division of Forestry

and Natural Resources. I would like to thank all of my committee members for their review and insight in shaping this thesis. 


\section{Table of Contents}

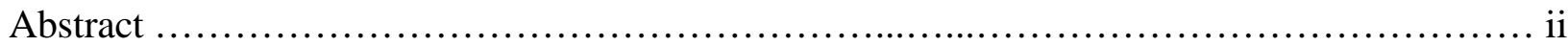

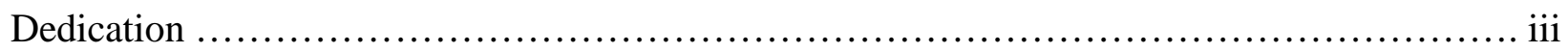

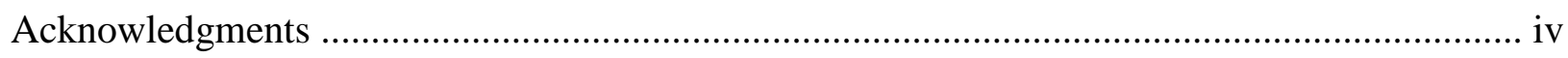

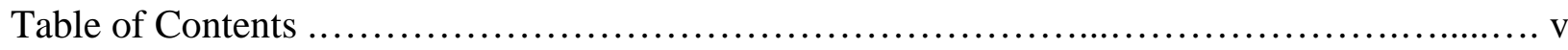

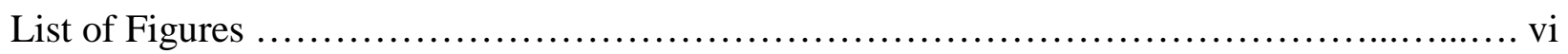

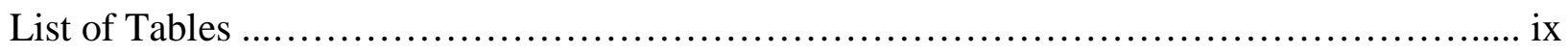

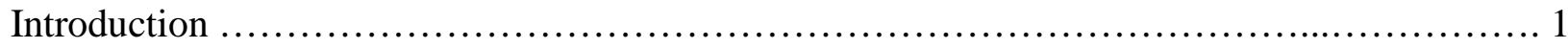

CHAPTER 1: Does Oil and Natural Gas Development Effect Mule Deer Survival? ............. 3

CHAPTER 2: Effects of Oil and Gas Development on Resource Selection of Female Mule Deer

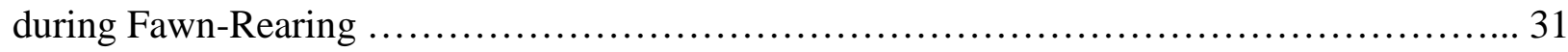

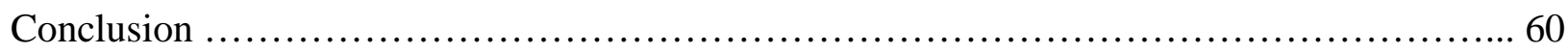

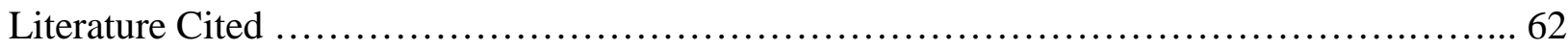




\section{LIST OF FIGURES}

Figure 1-1. Study areas for estimating mule deer survival in western North Dakota and eastern Montana, USA, between February 2013 and May 2016.

Figure 2-1. Circular buffer placed around the geographic median of the bi-weekly GPS locations, used in estimating survival covariates.

Figure 3-1. Bi-weekly survival probability of female mule deer (Odocoileus hemionus) in western North Dakota and eastern Montana, USA, between February 2013 and May 2016, in response to distance to nearest active oil drilling rig. Black lines represent model averaged survival probability and the shaded area represents the $95 \%$ confidence intervals.

Figure 4-1. Bi-weekly survival probability of female mule deer (Odocoileus hemionus) in western North Dakota and eastern Montana, USA, between February 2013 and May 2016, in response to distance to nearest primarylsecondary road. Black lines represent model averaged survival probability and the shaded area represents the $95 \%$ confidence intervals.

Figure 5-1. Bi-weekly survival probability of female mule deer (Odocoileus hemionus) in western North Dakota and eastern Montana, USA, between February 2013 and May 2016, in response to spring NDVI (left panel), snow depth (middle panel), and temperature (right panel). Black lines represent model averaged survival probability and the shaded area represents the 95\% confidence intervals.

Figure 6. Bi-weekly survival probability of female mule deer (Odocoileus hemionus) in western North Dakota and eastern Montana, USA, between February 2013 and May 2016, in response to age (right panel), season (middle panel), and study area (left panel). Black dots represent model averaged survival probability and the bars represent the $95 \%$ confidence intervals. 
Figure 1-2. Study areas for estimating mule deer rearing resource selection in western North Dakota and eastern Montana, USA, between 2013 - 2016.

Figure 2-2. Movement rate determined by GPS locations collected every 5 hours for an adult mule deer doe in western North Dakota from 01 May through 15 July 2013. Estimated date of parturition by the DeMars et al. (2013) method was 02 June (blue dots).

Figure 3-2. Estimated mean (point) and range of (horizontal lines) date of birth for adult female mule deer in western North Dakota and eastern Montana, USA, 2013 - 2016, using the DeMars et al. (2013) method compared to estimated date of parturition reported in the literature (black dot).

Figure 4-2. Estimated available habitat radius method described by Durner et al. (2009) for generation available units for selection. The used unit (green star) is the GPS location collected and 4 available units (black dots) randomly generate within the buffer of available habitat for selection.

Figure 5-2. Probability of an adult female mule deer within 8 weeks of parturition using a site as a function of distance to nearest oil and natural gas drilling rig, relative to a site located 0.5-km. This figure assumes all choices are 0 - 1-km from a drilling rig because the effect of distance to drilling rig is purely local, and diminishes as distance from drilling rig increases. Black lines represent the probability of selection as a rearing site and the shaded area represent the 95\% confidence intervals.

Figure 6-2. Probability of an adult female mule deer within 8 weeks of parturition using a site as a function of distance to nearest oil and natural gas well pad, relative to a site located 0.5-km. This figure assumes all choices are 0 - 1-km from a well pad. Black lines represent the 
probability of selection as a rearing site and the shaded area represent the $95 \%$ confidence intervals.

Figure 7-2. Probability of an adult female mule deer within 8 weeks of parturition using a site as a function of distance to nearest road, relative to a site located $0.5-\mathrm{km}$. This figure assumes all choices are $0-1-\mathrm{km}$ from a road because the effect of distance to primarylsecondary road is purely local, and diminishes as distance from primary/secondary road increase. Black lines represent the probability of selection as a rearing site and the shaded area represent the $95 \%$ confidence intervals.

Figure 8-2. Probability of an adult female mule deer within 8 weeks of parturition using a site as a function of distance to nearest water, with the lowest probability of use $0.42-\mathrm{km}$ away. Black lines represent the probability of selection as a rearing site and the shaded area represent the $95 \%$ confidence intervals. The vertical dotted line represents the distance from a water resource with the minima probability of use for like choice sets.

Figure 9-2. Probability of an adult female mule deer within 8 weeks of parturition using a site as a function of elevation, slope, and terrain ruggedness, with the greatest probability of use occurring at 751-m, 17 degrees, and 0.85, respectively. Black lines represent the probability of selection as a rearing site and the shaded area represent the $95 \%$ confidence intervals. The vertical dotted line represents the covariate value of highest probability of use.

Figure 10-2. Probability of an adult female mule deer within 8 weeks of parturition using a site as a function of cover type. This plot assumes a choice set with all cover type equally available, and all other variable constant across cover types. Points represent the probability of use as a rearing site and the $95 \%$ confidence intervals. 


\section{LIST OF TABLES}

Table 1-1. Capture summary for female mule deer captured in western North Dakota and eastern Montana via helicopter net-gunning and fitted with satellite global positioning system (GPS) telemeter collars programmed to collect a location every 5 hours in winter of 2012, 2013, and 2014.

Table 2-1. Summary of covariates and their form used in estimating female mule deer survival probability.

Table 3-1. Comparing model results for female mule deer survival covariate groups. Bold AIC values denote the model that was used in final model construction.

Table 4-1. Bi-weekly female mule deer survival models for western North Dakota and eastern Montana, USA, between February 2013 and May 2016, using 9,308 bi-weekly survival intervals, ranked by lowest AIC.

Table 5-1. Bi-weekly and annual adult female mule deer survival in western North Dakota in relation to the distance to nearest drilling rig assuming constant conditions for 12 months. Table 6-1. Bi-weekly and annual adult female mule deer survival in western North Dakota and eastern Montana in relation to the distance to nearest primarylsecondary road assuming constant conditions for 12 months.

Table 1-2. Capture summary for female mule deer captured in western North Dakota and eastern Montana via helicopter net-gunning and fitted with satellite global positioning system (GPS) telemeter collars programmed to collect a location every 5 hours in winter of 2012, 2013, and 2014. 
Table 2-2. Summary of covariates and the form used in estimating adult female mule deer rearing resource selection using discrete choice models.

Table 3-2. Model selection results for adult female mule deer rearing resource selection covariate groups using discrete choice models. Bold AIC values denote the model that was used in final model construction.

Table 4-2. Adult female mule deer rearing resource models for western North Dakota and eastern Montana, USA, 2013-2016, using 69,433 choice sets (69,433 used units and 277,732 available units), ranked by lowest AIC. 


\section{INTRODUCTION}

A worldwide increasing demand for both renewable and non-renewable energy resources has been ongoing for the past 50 years and is projected to continually increase for the next two decades (Copeland et al. 2009, Northrup and Wittemyer 2013, Beckmann et al. 2016). The increase in energy resource extraction in the United States has been driven by incentives to reduce foreign energy dependence (Copeland et al. 2009, Beckmann et al. 2016). Increased energy resource extraction and efficiency have been driven by advancements in technology, such as hydraulic fracturing (Clark 1949). Domestic energy resource extraction is projected to increase by 40\% over the next two decades (Northrup and Wittemyer 2013). Increased oil and natural gas development will ultimately increase the footprint of development on the landscape.

Wildlife may be affected by both direct and indirect means from oil and natural gas development. Direct impacts on wildlife from oil and natural gas development, such as habitat loss or alteration and habitat fragmentation, may occur through the development of well pads, roads, power lines, and pipelines (Walker et al. 2007, McDonald et al. 2009, Holloran et al. 2010, Hovick et al. 2014, Jones et al. 2015). These direct effects may lead to cascading indirect effects, such as avoidance, altered movement rates, and altered migration patterns (Sawyer et al. 2006, 2009, Lendrum et al. 2013, Northrup et al. 2015). Uncertainty around how oil and natural gas development could impact wildlife populations has raised concern for many wildlife species in developing landscapes.

Mule deer (Odocoileus hemionus) resource selection, behavior, and movement rates are also thought to be altered in the presence of oil and natural gas development. In landscapes with disturbance from oil and natural gas, mule deer alter space-use by avoiding developed areas and associated infrastructure such as roads and pipelines (Sawyer et al. 2006, 2009, Northrup et al. 
2015, 2016). Mule deer avoided areas with active drilling rigs at a greater distance compared to areas with only producing wells, which can extend up to 1-km from active drilling rigs (Sawyer et al. 2009, Northrup et al. 2015). Mule deer are more tolerant of well pads after the drilling infrastructure has been removed and the well is actively producing. Mule deer also avoided roads associated with oil and natural gas extraction. Mule deer avoided roads at a greater distance when traffic levels are higher and at greater distances during the day compared to during the night (Northrup et al. 2015 and Sawyer et al. 2009), which may be due to increased perception of predation risk around roads (Sawyer et al. 2009). Movement rates of migratory mule deer are also altered in oil and natural gas developed landscapes. Mule deer in highly developed landscapes left winter ranges later and migrated to summer ranges at a greater rate of speed than mule deer in less developed landscapes. Alteration in migration rates could have impacts on the individual's ability to acquire forage and ultimately influence demographic rates (Lendrum et al. 2013).

For this project, I evaluated the potential effects of oil and natural gas development on survival probability and rearing resource selection of mule deer. The role of oil and natural gas development in mule deer population dynamics is not well understood and determining the potential effects that oil and natural gas development have on mule deer survival and rearing resource selection can help inform managers on ways to mitigate potential adverse effects. 


\section{CHAPTER 1: Does Oil and Natural Gas Development Effect Mule Deer Survival?}

A worldwide increasing demand for both renewable and non-renewable energy resources has been ongoing for the past 50 years and is projected to continually increase for the next two decades (Copeland et al. 2009, Northrup and Wittemyer 2013, Beckmann et al. 2016). The increase in energy resource extraction in the United States has been driven by incentives to reduce foreign energy dependence (Copeland et al. 2009, Beckmann et al. 2016). Increased energy resource extraction and efficiency have been driven by advancements in technology, such as hydraulic fracturing (Clark 1949). Domestic energy resource extraction is projected to increase by 40\% over the next two decades (Northrup and Wittemyer 2013). Increased oil and natural gas development will ultimately increase the footprint of development on the landscape.

Wildlife may be affected by both direct and indirect means from oil and natural gas development. Direct impacts on wildlife from oil and natural gas development, such as habitat loss or alteration and habitat fragmentation, may occur through the development of well pads, roads, power lines, and pipelines (Walker et al. 2007, McDonald et al. 2009, Holloran et al. 2010, Hovick et al. 2014, Jones et al. 2015). These direct effects may lead to cascading indirect effects, such as avoidance, altered movement rates, and altered migration patterns (Sawyer et al. 2006, 2009, Lendrum et al. 2013, Northrup et al. 2015). Uncertainty around how oil and natural gas development could impact wildlife populations has raised concern for many wildlife species in developing landscapes.

Energy development in western North America has affected many wildlife species both directly and indirectly. A substantial amount of research in this area has focused on how energy development is altering habitat selection and abundance of affected wildlife. For example, greater sage-grouse (Centrocercus urophasianus) male lek recruitment was higher when leks 
were significantly further from drilling rigs, well pads, and roads (Holloran et al. 2010). Greater sage-grouse also avoided areas of coal-bed natural gas development during winter (Doherty et al. 2006). In fact, Hovick et al. (2014) concluded that grouse in oil and natural gas developed landscapes had a higher risk for displacement compared to other types of anthropogenically developed landscapes. Oil and natural gas development can influence passerine bird species as well. For example, abundances of Brewer's sparrow (Spizella breweri), sage sparrow (Amphispiza belli), and vesper sparrow (Pooecetes gramineus) were shown to decrease in areas of increased natural gas development (Gilbert and Chalfoun 2011). Increasing road density associated with natural gas extraction decreased occupancy probability for both the sagebrush sparrow (Artemisiospiza nevadensis) and sage thrasher (Oreoscoptes montanus) at a large scale (Mutter et al. 2015).

Ungulate populations have also shown behavioral responses to human disturbance, such as oil and natural gas development. Pronghorn (Antilocapra americanai) have been shown to alter winter habitat selection in natural gas fields compared to when development was absent from the landscape (Beckmann et al. 2012). Pronghorn abundance was negatively related to well pad density (Christie et al. 2015). Declines in woodland caribou (Rangifer tarandus) populations are thought to be caused by human disturbance with the exploration and development of petroleum (Bradshaw et al. 1997). Caribou have shown to avoid human disturbances (Vore et al. 2001), including seismic lines and roads associated with oil development (Dyer et al. 2001). Female elk (Cervus canadensis) in close proximity to natural gas fields had small home ranges, increased complexity of movement and increased movement rates compared to elk not within natural gas fields (Webb et al. 2011). 
Mule deer (Odocoileus hemionus) resource selection, behavior, and movement rates are also thought to be altered in the presence of oil and natural gas development. In landscapes with disturbance from oil and natural gas, mule deer avoided developed areas and associated infrastructure such as roads and pipelines (Sawyer et al. 2006, 2009, Northrup et al. 2015, 2016). Mule deer avoided areas with active drilling rigs at a greater distance compared to areas with only producing wells, which can extend up to 1-km from active drilling rigs (Sawyer et al. 2009, Northrup et al. 2015). The distance at which mule deer avoided drilling rigs is also dependent on time of day. During the night, mule deer avoided active drilling rigs at a greater distance compared to during the day (Northrup et al. 2015). Mule deer are more tolerant of well pads after the drilling infrastructure has been removed and the well is actively producing. The distance at which well pads cause an avoidance response varied during both day and night. Mule deer avoided producing wells out to 600-meters during the day; however, at night, mule deer show weak avoidance out to 400-meters (Northrup et al. 2015). The range of avoidance from all types of well pads is thought to be influenced by the topographic relief of the area. In areas with less topographic relief, mule deer display stronger avoidance distances from well pads than in areas of greater topographic relief (Northrup and Wittemyer 2013). Mule deer also avoid roads associated with oil and natural gas extraction. Mule deer avoided roads at a greater distance when traffic levels are higher and at greater distances during the day compared to during the night (Northrup et al. 2015 and Sawyer et al. 2009), which may be due to increased perception of predation risk around roads (Sawyer et al. 2009). Movement rates of migratory mule deer are also altered in oil and natural gas developed landscapes. Mule deer in highly developed landscapes left winter ranges later and migrated to summer ranges at a greater speed than mule deer in less developed landscapes. Alteration in migration rates could have impacts on the 
individual's ability to acquire forage and ultimately influence demographic rates (Lendrum et al. 2013).

Alterations in space use by mule deer in the presence of oil and natural gas development have been clearly demonstrated in the literature, but the effects on survival probability are still largely unknown. Increased road development for energy resource extraction can lead to increased access for hunting and recreational activities (Gratson and Whitman 2000). Creating more roads can also increase vehicle collisions, which can be a source of additive mortality (Litvaitis and Tash 2008, Meisingset et al. 2013). Traffic associated with energy development, recreation, and hunting can lead to greater energetic costs associated with fleeing from vehicles and increased vigilance, and decreased time spent foraging and resting, which could overall reduce survival rates (Ryan et al. 2014). These altered behaviors associated with oil and natural gas development could also cause increased stress, which could potentially reduce survival (Beckmann et al. 2016).

For this project, I evaluated the potential effects of oil and natural gas development on survival probability of mule deer. I contrast the survival probability of mule deer doe in North Dakota (ND), which has a higher level of oil and natural gas development, to neighboring populations in eastern Montana (MT) that have lower levels of oil and natural gas development. I evaluate the proximity and density of oil and natural gas development on survival while controlling for other sources of mortality, such as snow depth, temperature, and available forage. The role of oil and natural gas development in mule deer population dynamics is not well understood and determining the potential effects that oil and natural gas development have on mule deer survival can help inform managers on ways to mitigate potential adverse effects. 


\section{STUDY AREA}

This study occurred in western North Dakota (ND) and eastern Montana (MT) (Figure 1). Mule deer capture locations were located throughout the badlands and north to the Missouri River. Development for the extraction of oil and natural gas can be found in both study areas. However, most of the recent oil and natural gas development has occurred in ND, with a significant portion of the development in the northern region of the study area. The climate in this region is typically characterized by long cold winters and short hot summers. The average rain precipitation is 39-cm, with the majority occurring from May to September (Godfread 1994). Precipitation from snow fall is typically $30-\mathrm{cm}$. There is a collection of perennial streams that run throughout the study site, which drain into the Little Missouri River, Yellowstone River, and the Missouri River. The primary human disturbances in this study area can be attributed to ranching, farming, and infrastructure associated with gas and oil development. Row crops, hayed pastures and alfalfa planting, cattle grazing, well pads, roads, and pipelines are the main sources of human disturbance attributed to habitat loss, conversion, and fragmentation (J. L. Kolar et al., North Dakota Game and Fish, state report).

This region is characterized by highly-eroded, broken topography dominated by grassland and shrubland. Along the Little Missouri River and tributaries, silver sage (Artemisia cana) is the dominate shrub species and western wheatgrass (Agropyron smithii) is the principal grass (Godfread 1994). Cottonwood (Populus deltoids) and green ash (Fraxinus pensylvanica) are the primary tree species around water resources with buckbrush (Symphoricarpos occidentalis) as the primary understory species. Green ash is the pre-dominate tree species extending into upland draws with chokecherry (Prunus virginiana) as the primary shrub. Woody vegetation is typically located in draws and north-facing aspects and moderately steep slopes. 
The dominate woody vegetation is from various juniper species (Juniperus spp.), woods rose (Rose woodsii), and skunkbush (Rhus trilobata). South facing, moderate to steep slopes typically have sparse vegetation, if vegetated at all. These aspects are typically dominated by rabbitbrush (Chrysothamnus nauseosus), longleaf sage (Artemisia longifolia), and greasewood (Sarcobatus vermiculatus) (Godfread 1994). Grassland species distribution in this region is dependent on the soil type, moisture, and salinity. The most commonly found grasses are needle-and-thread (Stipa comate) and blue grama (Bouteloua gracilis). Little bluestem (Andropogon scoparius) is commonly found on moderate to steep slopes with a north to east aspect. Western wheatgrass, blue grama, and buffalo grass (Buchloe dactyloide) are found on gentle slopes with finer soil types. Forbs typically found in this area include buckwheat (Eriogonum multiceps), gumbo lily (Oenothera caespitosa), butte candle (Cryptantha celosoides), red mallow (Sphaeralcea coccinea), and prickly pear (Opuntia plycantha).

\section{METHODS}

\section{Capture and Handling}

We captured female mule deer via helicopter net-gunning in February 2013, December 2013, February 2014, and December 2014. We captured and collared 101 adults and 106 juveniles in ND and 30 adults and 43 juveniles in MT (Table 1). Female mule deer were fitted with satellite global positioning system (GPS) radio-collars (G2110L Iridium and G2110L Iridium; Advanced Telemetry System Inc. [ATS], Isanti, MN). The collars were programed to collect a location every 5 hours. Location data was transmitted every 4 days via satellite which allowed for the data to be collected without disturbing the deer. Collars were programmed to activate a 'mortality mode' if no activity was detected for $>6$ hours. Once in mortality mode, 
the collar would transmit a real-time mortality notification and hourly coordinates until either activity was detected or the collar was retrieved.

\section{Survival and Covariate Estimation}

I evaluated mule deer survival using logistic regression, which is equivalent to knownfate survival models. I treated bi-weekly survival as a Bernoulli random variable:

$$
y_{i t} \sim \operatorname{Bernoulli}\left(\theta_{i t}\right) \text {, }
$$

where $y_{i t}$ is a random variable denoted as 1 (survived) or 0 (died) during the 2-week interval and $\theta_{i t}$ is the probability that individual $i$ will survive during time interval $t$. I used a bi-weekly time interval because it allowed me to obtain sufficient locations for evaluating bi-weekly home ranges from which I calculated spatial covariates (details below). Individuals were censored from the analysis if they did not live 2-weeks post-collaring.

I recorded spatial covariates based on mule deer locations within each bi-weekly interval. For each mule deer, I calculated spatial covariates using equal-sized circular buffers (3.54-km²), which were centered at the median $\mathrm{x}$ and $\mathrm{y}$ coordinates within each bi-week interval (hereafter bi-weekly centroid). I calculated the radius (1060.9-m) of this circular buffer by first calculating bi-weekly home ranges for each mule deer using a 99\% kernel density estimator (KDE) with package ‘ks’ version 1.10.7 (Duong 2017) in program R version 3.4.2 (R Core Team 2017). After obtaining the median home range size, I then calculated the radius of a circle with equivalent area, which I used when constructing circular buffers (Figure 2).

Spatial covariates were then measured based on the bi-weekly centroid and circular buffer described above. Oil and natural gas development covariates were collected from the North Dakota Industrial Commission, Oil and Gas Division, ArcIMS viewer (NDIC 2017). I 
classified well pads into two categories: drilling rig or active well pad. A pad was classified as a drilling rig for any period of time when a well was being actively drilled on the pad. The pad then transitioned to an active well pad after the drilling infrastructure was removed from the site and there was at least one well on the pad producing oil or natural gas. Development covariates included linear distance from the bi-weekly centroid to the nearest drilling rig and active well pad. I calculated distance to nearest drilling rig and active well pad using the gDistance function within the 'rgeos' packing version 0.3-25 (Bivand et al. 2017) in program $\mathrm{R}$ version 3.4.2. I calculated presence/absence and density of drilling rigs and active well pads within the circular buffer during each bi-weekly interval due to the dynamic nature of drilling rigs.

I also collected covariates associated with human development that were not necessarily a consequence of oil and natural gas development. I obtained road data from the North Dakota Department of Transportation (NDDOT 2016) and manually digitized missing roads from 2015 aerial imagery at a 1:5,000 scale. Gravel pit locations were determined using a point shapefile from the North Dakota GIS hub portal. From these layers, I calculated linear distance from the bi-weekly centroids to the nearest primary/secondary road and gravel pit using the gDistance function within the 'rgeos' package version 0.3-25. Road density was determined by dividing road length within the circular buffer by the area of the circular buffer. Gravel pit presence/absence and density was calculated within the circular buffer. I calculated gravel pit density by dividing the total count of gravel pits within the circular buffer divided by the buffered area.

I also measured environmental variables not associated with human development. I used the Normalized Difference Vegetation Index (NDVI) as a proxy for mule deer forage quality (Hurley et al. 2014). I calculated NDVI for each successful GPS location using Movebank’s 
Env-DATA interface (Dodge et al. 2013, Wikelski and Kays 2017). Band 1 (red) and band 2 (near infrared) are collected daily at a 250-meter resolution (https://lpdaac.usga.gov/), from which I calculated NDVI

$$
\text { NDVI }=(\text { band } 2-\text { band } 1) /(\text { band } 2+\text { band } 1)
$$

(Jackson and Huete 1991). For each mule deer, I averaged NDVI values obtained at each GPS location for each bi-weekly interval. I assigned surface snow depth values for each successful GPS location using Movebanks Env-DATA interface (Dodge et al. 2013 and Wikelski and Kays 2017). Snow depth was recorded at a 250-meter resolution, and interpolated from the National Center for Environmental Prediction (NCEP) North American Regional Reanalysis (NARR) model (http://rda.ucar.edu/datasets/ds608.0/index.html\#sfol-wl-/data/ds608.0?g=3, last accessed 20 November, 2017). For each mule deer, I averaged snow depth values obtained at each GPS location for each bi-weekly interval. Each collar was equipped with an onboard thermometer, and temperature was recorded with each successful GPS fix. I averaged the onboard temperature data over each bi-weekly interval. Home range size was calculated using a 99\% KDE for all points collected during each bi-weekly interval. Home range size for each bi-weekly interval was retained from calculating the median home range size for the circular buffer. I also wanted to test for variations within the study area that could have attributed to differences in survival. To do this we incorporated geographic location which was determined for each interval using the bi-weekly centroid.

Finally, non-spatial covariates were also collected for each bi-weekly interval. I aged mule deer as either adult ( $\geq 18$ months) or juveniles ( $\leq 8$ months) at capture. I graduated all juveniles to the adult cohort if they survived to the next biological year (01 June; thus, I only have data for juveniles from December captures through 01 June). I used the following seasons: 
spring (01 April - 31 May), summer (01 June - 30 September), autumn (01 October - 30

November), and winter (01 December - 31 March). Biological year was recorded for each biweekly interval and each biological year started on 01 June.

\section{Model Selection}

The first step in model selection was to determine which form (quadratic, pseudothreshold, and linear) was most appropriate for each continuous covariate. I determined this by fitting univariate models - only 1 variable at a time - with each of the 3 forms. Each covariate form was evaluated using Akaike Information Criterion (AIC) and the form with the lowest AIC was used in final model construction.

The next step in model construction was to determine the co-linearity between like covariates and determine which to use in model construction. I fit univariate models with any covariates that had an absolute Pearson correlation coefficient value greater than 0.85. I ranked the highly correlated variables by AIC and the covariate with the lowest AIC was used in model construction.

After determining which forms and variables to include in the model, I grouped covariates into 3 groups: background (environmental and non-spatial covariates), oil and natural gas, and road and gravel pit covariates (Table 2). I first wished to obtain a parsimonious set of variables within each group. Within each covariate group, I fit 'full' models that included all covariates within that group. I then fit 'reduced' models that contained only covariates from the full model that had an absolute value of the ratio of point estimate to standard error (i.e., a Wald test statistic) $>1.64$. I then compared full and reduced models within each covariate group using AIC and the model with the lowest AIC was used in final model construction (Table 3). Once I 
found the most parsimonious model for each covariate group, I then fit 8 models representing all combinations of covariate groups (Table 4). I ranked models using AIC and averaged slope coefficients over all models with delta AIC $<2$ using package 'AICcmodavg' in program $\mathrm{R}$ (Mazerolle 2017, 2.1-1).

\section{RESULTS}

Survival probabilities were estimated from 268 mule deer and were comprised of 9,308 bi-weekly intervals from February 2013 through May 2016. The top model included oil and natural gas variables, and models with oil and natural gas variables accounted for $58 \%$ of model weight (Table 4). Thus, models containing oil and natural gas variables improved model performance compared to when those variables were left out of the model. As mule deer moved further from drill rigs survival increased but showed a pseudo-threshold response. For example, mule deer survival is predicted to decrease $7 \%$ when they were $0.1-\mathrm{km}$ from a drilling rig compared to when they were 2-km from a drilling rig (Table 5). Given the pseudo-threshold nature of the response, the effect of proximity to oil and natural gas was local and did not have a meaningful effect on survival probability at larger distances (Figure 3). However, substantial model selection uncertainty led to associates uncertainty in predicted effects on survival probability (Figure 3). I did not detect any relationship between mule deer survival probability and distance to nearest active well pad or the presencelabsence of an active well pad within the circular buffered area.

The top model also included road and gravel pit variables, and models with road and gravel pit variables accounted for $60 \%$ of model weight (Table 4). Thus, models containing oil and natural gas variables improved model performance compared to when those variables were left out of the model. As deer moved further away from primarylsecondary roads, survival 
increased but showed a quadratic relationship (Figure 4). For example, mule deer survival is predicted to decrease $2.5 \%$ when they were $0.5-\mathrm{km}$ from a road compared to when they were 1.5-km from a road (Table 6). However, there was substantial model selection uncertainty in the predicted effects on survival probability (Figure 4). There was no relationship detected between road density or distance to nearest gravel pit and mule deer survival probability.

The most influential environmental covariates on mule deer survival were background variables not associated with oil and natural gas development. Background variables were included in all of the top 4 models and comprised $100 \%$ of model weight. Mule deer survival probability was negatively related to surface snow depth in spring (Figure 5). Survival probability was positively related to spring temperature (Figure 5). There was a weak negative relationship between summer temperature and survival probability. As summer temperatures increased, mule deer survival probability decreased, but this relationship had substantial uncertainty. Survival probability was negatively related to spring NDVI value (Figure 5).

Age and season were also strongly related to mule deer survival. Adult survival probabilities were greater than juvenile survival probabilities (Figure 6). Survival probabilities were lower in spring and winter compared to summer and autumn (Figure 6). There was no difference in survival probabilities between the ND and MT reference study areas (Figure 6).

\section{DISCUSSION}

I found evidence that oil and natural gas development may have a weak effect on survival probability of mule deer in western North Dakota. Mine is the first to document a direct, albeit weak, link between oil and natural gas exploration and survival probability of mule deer. Mule deer coming out of winter are typically on strict energy budgets and increased movement or 
stress associated with development could be lethal (Bradshaw et al. 1997). I also found evidence to suggest that roads have a weak effect on mule deer survival probability. Mule deer located closer to roads could be experiencing decreased survival related to increased vigilance and perceived predation risk leading to increased flight energy expenditures. Increased vigilance can decrease the amount of time spent on biological needs such as foraging and resting (Bradshaw et al. 1997).

A possible reason for observing the weak relationship between oil and natural gas covariates and survival probability may be because mule deer avoid areas of active development (Skelly 2018). Sawyer et al. (2006, 2009) and Northrup et al. (2015) documented mule deer avoidance of all types of oil and natural gas development (i.e., active drilling rigs and well pads) in Wyoming and Colorado, respectively. Northrup et al. (2015) found that mule deer were strongly avoiding areas within 800-meters of a well pad, and were able to detect avoidance out to 1000-meters.

I detected the strongest relationship between survival probabilities and background variables. Mule deer survival was lower in winter and spring compared to summer and autumn. This result is similar to other studies on mule deer survival in northern latitudes (White et al. 1987, Bishop et al. 2005, Lomas and Bender 2007, Carnes 2009, Hurley et al. 2011, Brodie et al. 2013) as well as previous population models on mule deer in western North Dakota (Ciuti et al. 2015). I detected a strong negative relationship between mule deer survival and snow depth in spring. Mule deer coming out of winter tend to be in a negative energy balance and a spring snow could make restoring fat reserves more difficult and increase energy expenditure (Wallmo 1981, Nelson and Mech 1986). Increased snow depth also limits the amount of available forage and makes digging for grasses and forbs more difficult. When snow is present it adds energy 
expenditures for traversing the landscape and can also impede predator evasion. Nelson and Mech (1986) documented that increased snow depth led to increased predation rates of whitetailed deer from wolves. During the spring of 2014, there was a lot of ice on the landscape (J. L. Kolar, North Dakota Game and Fish, personal communication) and mule deer were possibly unable to reach forage below and made traversing the landscape more difficult. This icy spring could be driving the trend of snow pack, decreasing mule deer survival probabilities. I also detected a strong relationship between mule deer survival and temperature in spring. Cold temperatures increase the demand for maintaining body heat thus increasing energy needs (Nelson and Mech 1986, Ciuti et al. 2015, Beckmann et al. 2016). The two main hypotheses for observing these trends are increased predation risk and deceased forage availability. Periods of cold weather and deep snow have attributed to malnutrition, increased competition, and decreased ability to flee from predators (Bishop et al. 2005, Ciuti et al. 2015, and Beckmann et al. 2016). During this time period, mule deer are typically in a negative energy balance and relying on fat storages built up during the summer and fall months (Wallmo 1981).

I found that mule deer survival probability was negatively related to NDVI in the spring, which was the opposite of what I expected. I expected NDVI to capture spatial variation in forage availability, and thus to be positively related to survival probability. This result could be driven by a harsh winter and spring that depleted fat reserves too low that mule deer were unable to recover regardless the amount of forage on the landscape. Although Davis et al. (2016) concluded that annual integrated NDVI values were a significant predictor of roe deer survival, the NDVI collection method for this project may not have directly captured the actual amount of available forage on the landscape and therefore made it an unreliable covariate for describing mule deer survival. Alternatively, NDVI may have been a stronger proxy for other variables that 
drove mule deer survival. For example, high NDVI values may have been associated with complex vegetation structure that provided hiding cover for mule deer predators.

Finally, I also found that adult survival was higher and less variable than juvenile survival, which is congruent with the ungulate literature. White et al. (1987), Bishop et al. (2005), and Lukcas et al. (2008) found that adult female mule deer survival was higher and less variable than juvenile survival. This is because juveniles are more susceptible to predation and are more naïve to roads and vehicles.

\section{MANAGEMENT IMPLICATIONS}

I have demonstrated that active drilling rigs on the landscape may have a weak effect on mule deer survival probability. Limiting active drilling times to during the summer and autumn, when mule deer are not energetically stressed, could reduce the impact for mule deer on strict energy budgets during the late winter and spring. Consolidating infrastructure may be a possible way to reduce the amount of impact on mule deer and other species (Sawyer et al. 2006, 2009, Northrup et al. 2016, Skelly 2018). One way to consolidate infrastructure may be the use of horizontal drilling, which will allow for the consolidation of multiple wells to a single well pad (Clark 1949, Sawyer et al. 2009). While this will likely increase the size of the well pad it will limit the amount of well pads on the landscape. I also observed moderate effects of roads on mule deer survival probability. Another way to consolidate oil and natural gas associated infrastructure would be to place well pads near pre-existing roads, therefore, reducing the amount of roads on the landscape (Northrup et al. 2015). Fewer roads will allow mule deer to remain at intermediate distance from a road which should help increase survival. Also, limiting the construction of new roads will lower the amount of habitat loss either directly or indirectly due to avoidance. 
Pre-development planning should identify areas with low mule deer densityllow probability of mule deer use. Future development should be concentrated in areas identified as low density/use by mule deer. Well pads could then implement horizontal drilling and extract oil or natural gas from areas identified as high mule deer density/high probability of use while reducing surface impacts (Sawyer et al. 2009). 


\section{FIGURES}

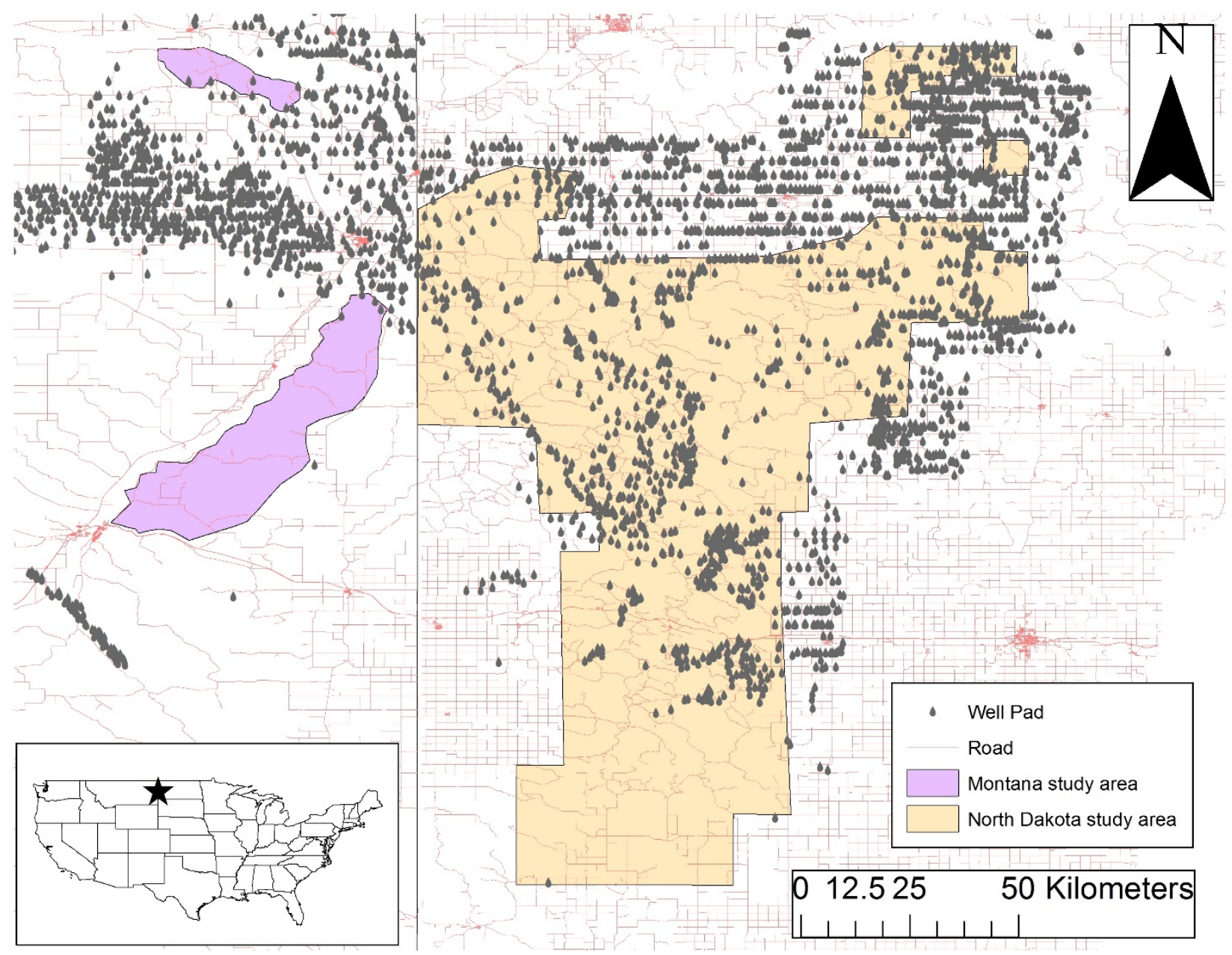

Figure 1. Study areas for estimating mule deer survival in western North Dakota and eastern

Montana, USA, between February 2013 and May 2016. 


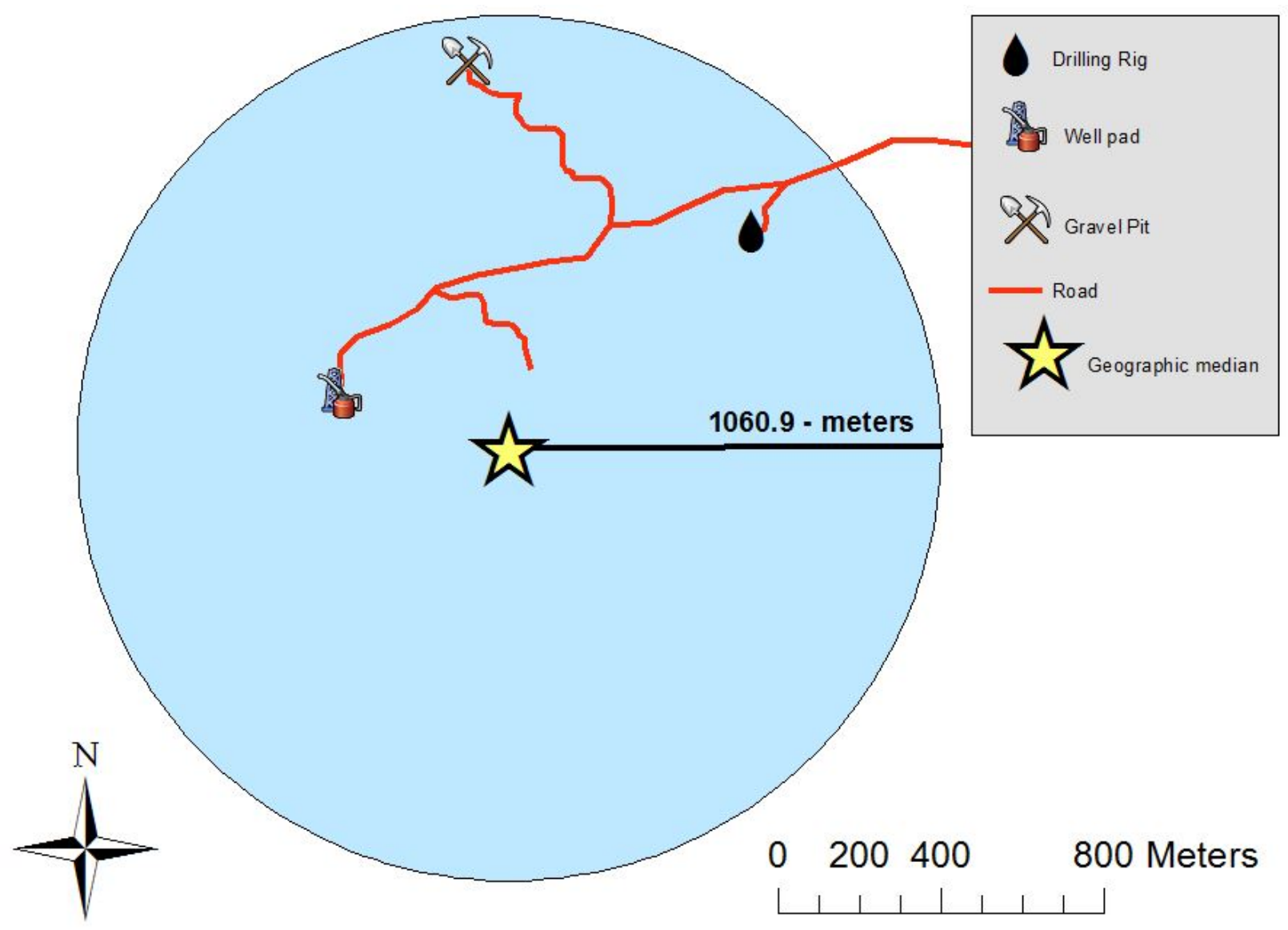

Figure 2. Circular buffer placed around the geographic median of the bi-weekly GPS locations, used in estimating survival covariates. 

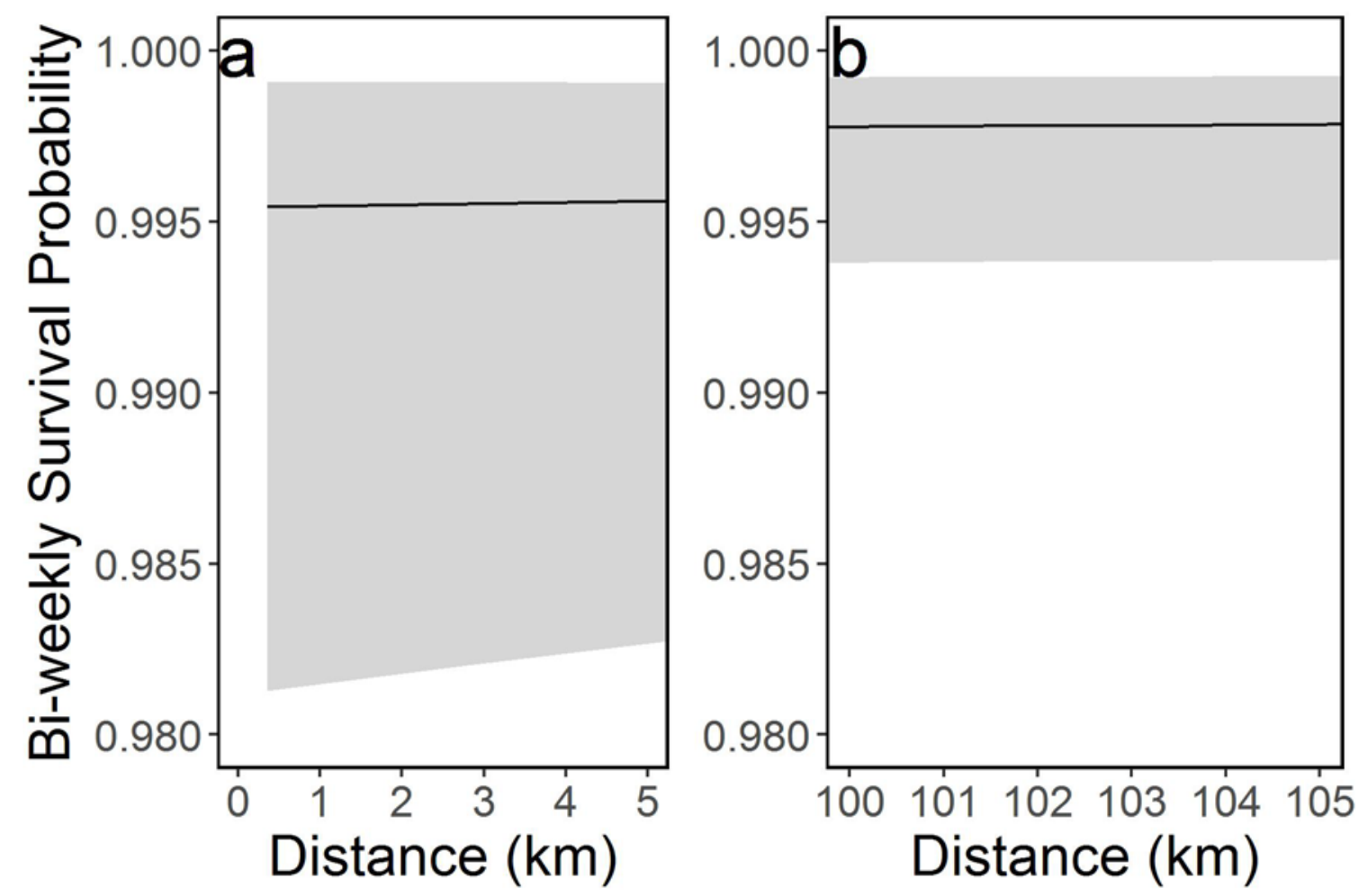

Figure 3. Bi-weekly survival probability of female mule deer (Odocoileus hemionus) in western North Dakota and eastern Montana, USA, between February 2013 and May 2016, in response to distance to nearest active oil drilling rig. Black lines represent model averaged survival probability and the shaded area represents the 95\% confidence intervals. 


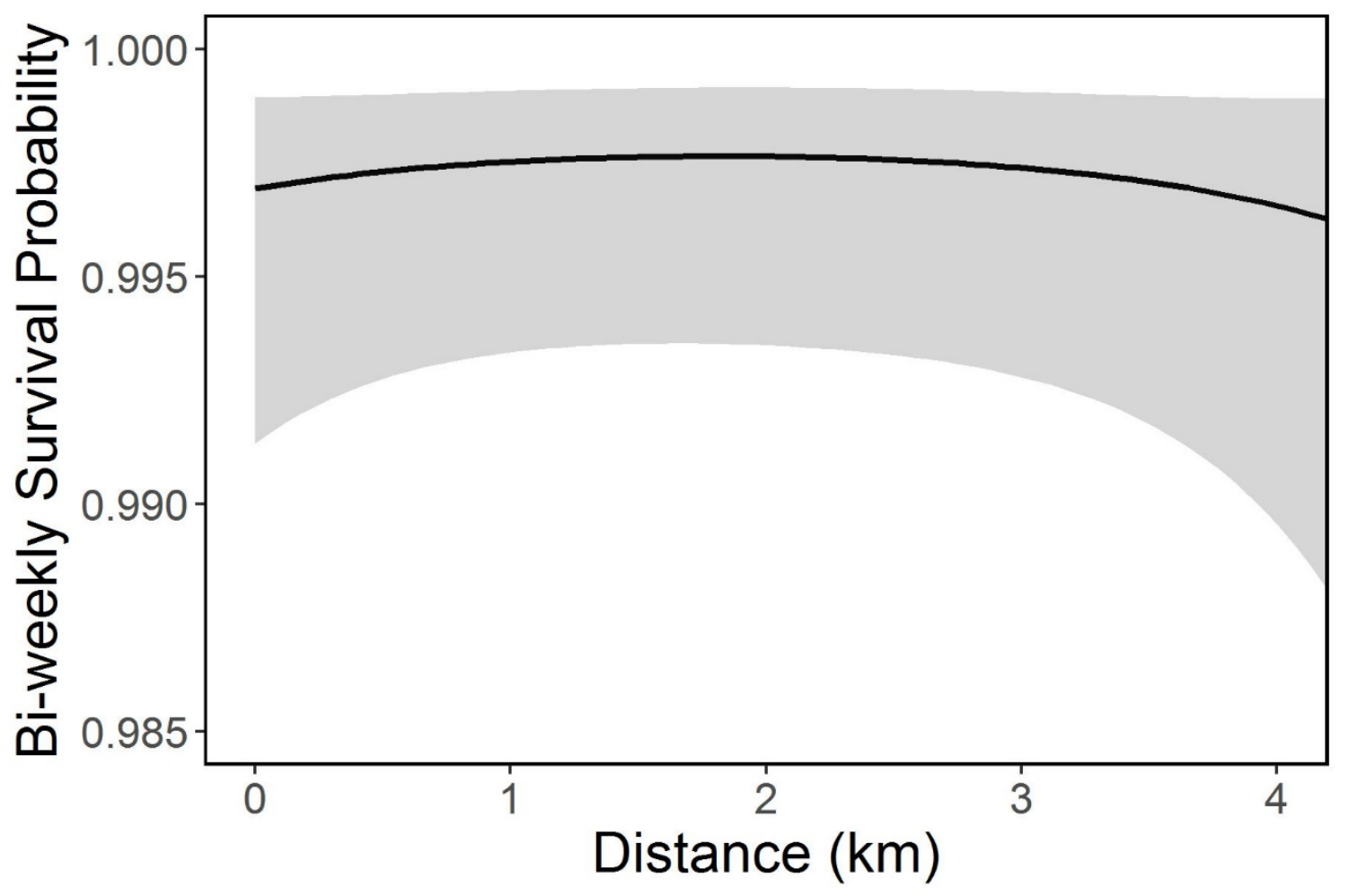

Figure 4. Bi-weekly survival probability of female mule deer (Odocoileus hemionus) in western North Dakota and eastern Montana, USA, between February 2013 and May 2016, in response to distance to nearest primary\secondary road. Black lines represent model averaged survival probability and the shaded area represents the 95\% confidence intervals. 


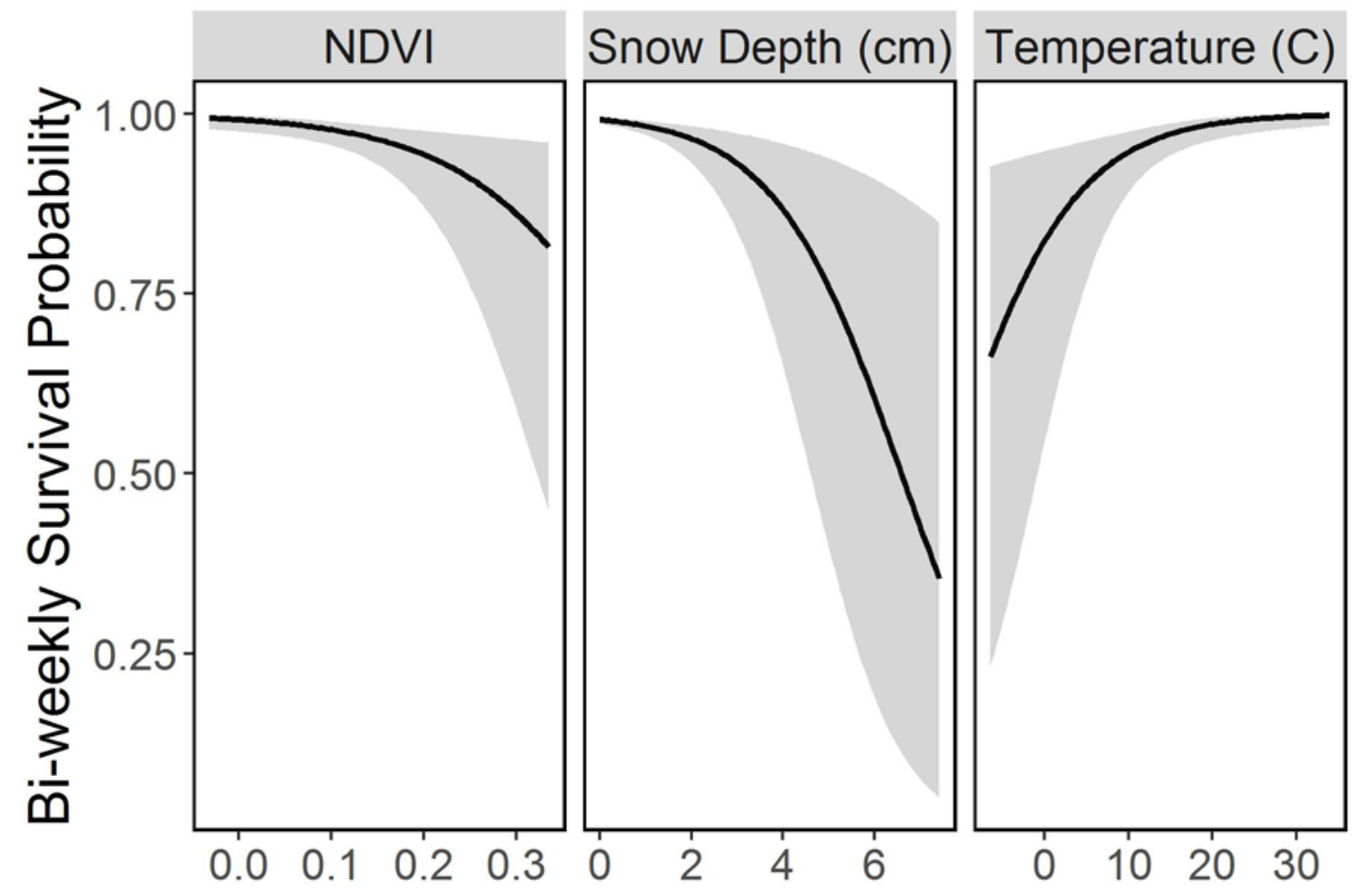

Figure 5. Bi-weekly survival probability of female mule deer (Odocoileus hemionus) in western North Dakota and eastern Montana, USA, between February 2013 and May 2016, in response to spring NDVI (left panel), snow depth (middle panel), and temperature (right panel). Black lines represent model averaged survival probability and the shaded area represents the $95 \%$ confidence intervals. 

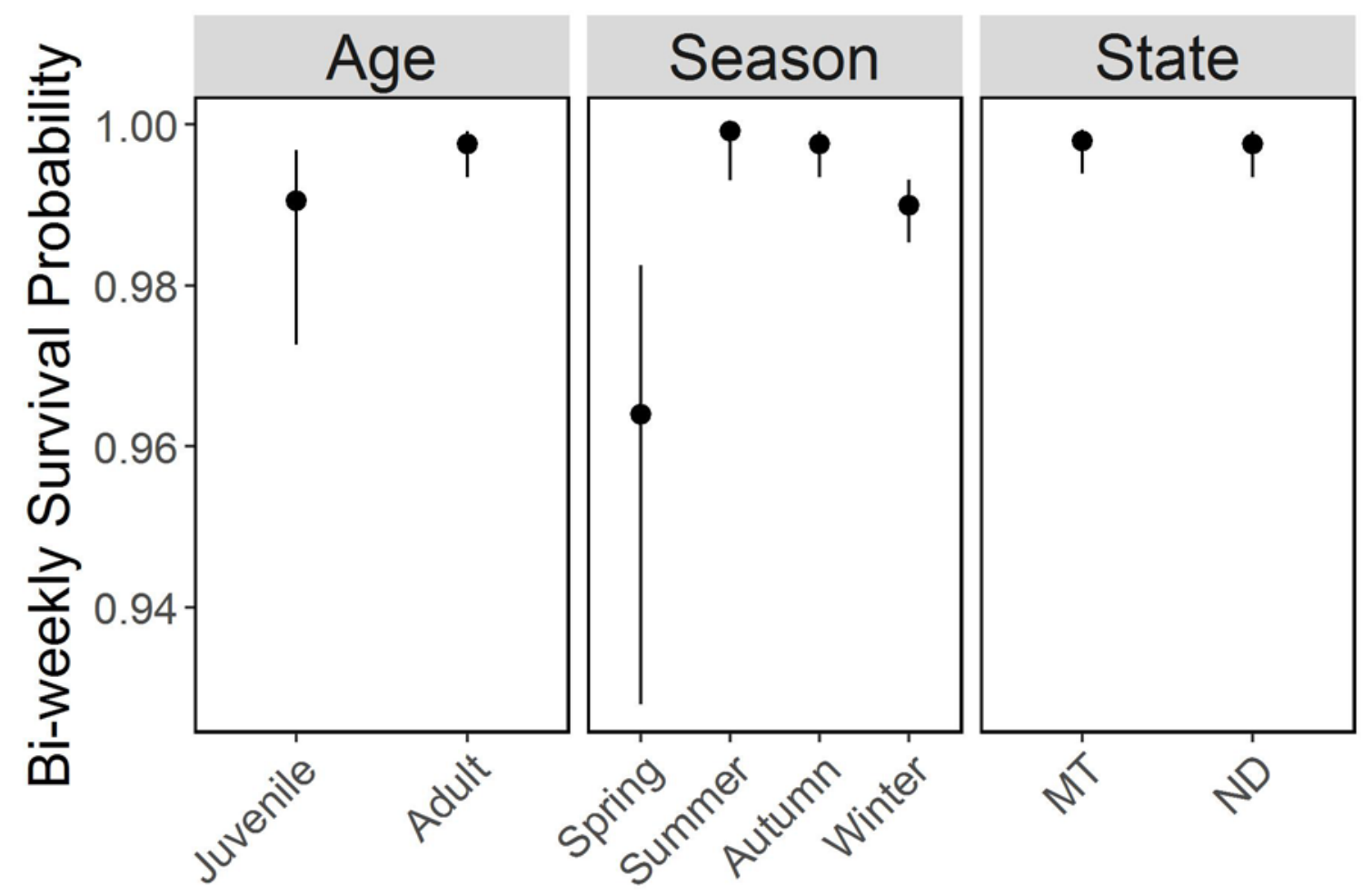

Figure 6. Bi-weekly survival probability of female mule deer (Odocoileus hemionus) in western North Dakota and eastern Montana, USA, between February 2013 and May 2016, in response to age (right panel), season (middle panel), and study area (left panel). Black dots represent model averaged survival probability and the bars represent the 95\% confidence intervals. 


\section{TABLES}

Table 1. Capture summary for female mule deer captured in western North Dakota and eastern Montana via helicopter net-gunning and fitted with satellite global positioning system (GPS) telemeter collars programmed to collect a location every 5 hours in winter of 2012, 2013, and 2014.

\begin{tabular}{ccccccc}
\hline & \multicolumn{3}{c}{ North Dakota } & \multicolumn{3}{c}{ Montana } \\
\hline Capture Year & Adult & Juveniles & Total & Adult & Juveniles & Total \\
$2012^{*}$ & 60 & 30 & 90 & - & - & - \\
2013 & 16 & 30 & 46 & 20 & 20 & 40 \\
2014 & 25 & 46 & 71 & 10 & 23 & 33 \\
Total & 101 & 106 & 207 & 30 & 43 & 73 \\
\hline
\end{tabular}

*The 2012 captures were delayed until February, 2013. 
Table 2. Summary of covariates and their form used in estimating female mule deer survival probability.

\begin{tabular}{|c|c|c|}
\hline Covariate Group & Parameter & Form \\
\hline \multirow[t]{15}{*}{ Background } & Age (Juvenile, adult) & Linear \\
\hline & Biological year (2013, 2014, 2015, 2016) & Linear \\
\hline & Seasons (Spring, Summer, Autumn, Winter) & Linear \\
\hline & Spring * NDVI & Linear \\
\hline & Summer $*$ NDVI & Linear \\
\hline & Autumn * NDVI & Linear \\
\hline & Spring * Snow depth & Linear \\
\hline & Winter $*$ Snow depth & Linear \\
\hline & Autumn * Snow depth & Linear \\
\hline & Spring * Temperature & Linear \\
\hline & Summer $*$ Temperature & Linear \\
\hline & Autumn * Temperature & Linear \\
\hline & Winter $*$ Temperature & Linear \\
\hline & Home range area & Linear \\
\hline & Geographic location & Linear \\
\hline \multirow[t]{4}{*}{ Gas and Oil Development } & State (North Dakota, Montana) & Linear \\
\hline & Distance to nearest rig & Pseudo-threshold \\
\hline & Distance to nearest well pad & Pseudo-threshold \\
\hline & Well pad presence/ absence & Linear \\
\hline \multirow[t]{3}{*}{ Road and Gravel Pit } & Distance to nearest road & Quadratic \\
\hline & Road density & Linear \\
\hline & Distance to nearest gravel pit & Linear \\
\hline
\end{tabular}


Table 3. Comparing model results for female mule deer survival covariate groups. Bold AIC values denote the model that was used in final model construction.

\begin{tabular}{|c|c|c|c|}
\hline Group & Model & Variables & AIC \\
\hline \multirow[t]{2}{*}{ Background } & Full & $\begin{array}{l}\text { Age (Juvenile, adult) } \\
\text { Year (2013, 2014, 2015, 2016) } \\
\text { Season (Spring, Summer, Autumn, Winter) } \\
\text { Spring * Snow depth } \\
\text { Autumn * snow depth } \\
\text { Winter * snow depth } \\
\text { Spring * NDVI } \\
\text { Summer * NDVI } \\
\text { Autumn * NDVI } \\
\text { Spring * temperature } \\
\text { Summer * temperature } \\
\text { Autumn * temperature } \\
\text { Winter * temperature } \\
\text { home range area } \\
\text { Easting by Northing }\end{array}$ & 1027.7 \\
\hline & Reduced & $\begin{array}{l}\text { Age (Juvenile, adult) } \\
\text { Season (Spring, Summer, Autumn, Winter) } \\
\text { Spring * Snow depth } \\
\text { Spring * NDVI } \\
\text { Spring * temperature } \\
\text { Summer * temperature }\end{array}$ & 1015.9 \\
\hline \multirow[t]{2}{*}{ Development } & Full & $\begin{array}{l}\text { State (North Dakota, Montana) } \\
\text { State (North Dakota) * drilling rig distance } \\
\text { well pad distance } \\
\text { well pad presence/absence } \\
\text { well pad distance * well pad presence/absence }\end{array}$ & 1111.8 \\
\hline & Reduced & $\begin{array}{l}\text { State (North Dakota, Montana) } \\
\text { State (North Dakota) * drilling rig distance }\end{array}$ & 1107.5 \\
\hline \multirow[t]{2}{*}{ Road and Gravel Pit } & Full & $\begin{array}{l}\text { Road distance } \\
\text { Road distance }{ }^{2} \\
\text { Road density } \\
\text { Gravel pit distance }\end{array}$ & 1104.2 \\
\hline & Reduced & $\begin{array}{l}\text { Road distance } \\
\text { Road distance }^{2}\end{array}$ & 1103.6 \\
\hline
\end{tabular}


Table 4. Bi-weekly female mule deer survival models for western North Dakota and eastern Montana, USA, between February 2013 and May 2016, using 9,308 bi-weekly survival intervals, ranked by lowest AIC.

\begin{tabular}{lcccc}
\hline \multicolumn{1}{c}{ Model Parameters } & K & AIC & DAIC & Model Weight \\
\hline Global & 13 & 1014.45 & 0.00 & 0.37 \\
Background + Road and Gravel Pit & 11 & 1015.43 & 0.98 & 0.23 \\
Background + Oil/Gas Development & 11 & 1015.56 & 1.11 & 0.21 \\
& & & & 0.18 \\
\hline Background & 9 & 1015.86 & 1.41 & \\
\hline
\end{tabular}


Table 5. Bi-weekly and annual adult female mule deer survival in western North Dakota in relation to the distance to nearest drilling rig assuming constant conditions for 12 months.

\begin{tabular}{lll}
\hline \multicolumn{1}{c}{ Rig Distance (km) } & \multicolumn{1}{c}{ Bi-weekly Survival Rate } & \multicolumn{1}{c}{ Annual Survival Rate } \\
\hline 0.1 & $99.4 \%$ & $85.5 \%$ \\
1.0 & $99.6 \%$ & $90.1 \%$ \\
2.0 & $99.7 \%$ & $92.5 \%$ \\
3.0 & $99.7 \%$ & $92.5 \%$ \\
\hline
\end{tabular}


Table 6. Bi-weekly and annual adult female mule deer survival in western North Dakota and eastern Montana in relation to the distance to nearest primarylsecondary road assuming constant conditions for 12 months.

\begin{tabular}{|c|c|c|}
\hline Distance & Bi-weekly Survival Rate & Annual Survival Rate \\
\hline 0.5 & $99.7 \%$ & $92.5 \%$ \\
\hline 1.5 & $99.8 \%$ & $95.0 \%$ \\
\hline 2.5 & $99.8 \%$ & $95.0 \%$ \\
\hline 3.5 & $99.7 \%$ & $92.5 \%$ \\
\hline
\end{tabular}




\section{CHAPTER 2: Effects of Oil and Gas Development on Resource Selection of Female Mule Deer during Fawn-Rearing}

North American ungulates typically give birth to neonates that are relatively immobile and hide at the parturition site (McGraw et al. 2014). Following parturition, the neonate is most susceptible to mortality from predation during the first few weeks of life. Survival probability over this brief timeframe can be critically important to populations because population growth rates are often highly sensitive to changes in neonate survival (Barten et al. 2001, McGraw et al. 2014, Lehman et al. 2016). Changes in sensitive demographic rates, such as recruitment, have the ability to influence abundance (Pac and White 2007, Lukacs et al. 2008, Grovenburg et al. 2012, Brodie et al. 2013, Beckmann et al. 2016). Furthermore, the dam is also under a lot of nutritional stress from energy needs for rearing young. Therefore, the dam will need to select rearing sites that have access to high-quality forage while also mitigating predation risk to her and her neonate(s) (Long et al. 2009, Lehman et al. 2016).

During the fawn rearing season, the dam must acquire high-quality forage to replenish fat reserves lost during winter, as well as offset the increasing energy demands associated with gestation and lactation (Fox and Krausman 1994, Bowyer et al. 1999, Long et al. 2009, Brook 2010, Rearden et al. 2011). The nutritional demands for females peaks at approximately 4-6 weeks post parturition (Long et al. 2009). The dam is typically restricted to the area around the birth site for anywhere from a couple of days up to a few weeks (Bowyer et al. 1991, 1999, Barbknecht et al. 2011, McGraw et al. 2014), therefore, it is important to have available forage on or near the site. Given these energetic demands and limited mobility, many North American ungulates have been shown to use parturition sites with high-quantity forage relative to what was available (Bowyer et al. 1999, Brook 2010, Barbknecht et al. 2011, Rearden et al. 2011). 
Selection by the dam for areas with high-quality forage is typically associated with a trade-off for higher predation pressure (Bowyer et al.1999, Rearden et al. 2011).

Several landscape features can contribute to forage availability. Southwesterly exposures typically receive more sunlight which may promote earlier emerging forage and greater forage availability. Moose (Alces alces) and elk (Cervus canadensis) calving locations have been described as being located on southeasterly exposures (Bowyer et al 1999 and Barbknecht et al. 2011) presumably to take advantage of foraging resources. Furthermore, the on-set of lactation increases the demand for water (Long et al. 2009). As a consequence, moose and mule deer rearing habitat has been described as being close to water bodies (Leptich and Gilbert 1986, Long et al. 2009, and McGraw et al. 2011).

Although dams must select sites that meet nutritional demands, they must balance this by also selecting sites that minimize predation pressure (Bowyer et al.1999, Rearden et al. 2011). Due to the limited mobility of the neonate, concealment cover for hiding has been shown to be critical to avoid detection from predators. Hiding cover can come in the form of vegetative structure as well as physical landscape features. Increased amounts of hiding cover are important in elk, moose, and mule deer rearing habitat (Langley and Pletscher 1994, Lomas and Bender 2007, Scarpitti et al. 2007, Brook 2010, Barbknecht et al. 2011). Increased canopy cover will decrease the amount of understory vegetation, therefore, allowing the dam to have better visibility and detection of predators (Rearden et al 2011). Different levels of canopy cover will allow different amount of sunlight on the forest floor making patches of sunny and shaded areas. This patchiness will increase the ability of the neonate to hide from predators (Bowyer et al. 1999 and Rearden et al. 2011). Moose calving locations have been described in areas of greater tree canopy cover (Langley and Pletscher 1994), while elk and mule deer have been located in 
more open-canopy cover (Long et al. 2009, Rearden et al. 2011, Lehman et al. 2016). Physical landscape features that are associated with hiding cover can broadly be described as elevation, terrain ruggedness, and slope. Selection for areas of higher elevation is attributed to lower predation pressures because ungulates are thought to be moving away from predators. Areas of higher elevation can also provide the dam with a greater view of the surrounding area and detect predators before she is detected. Elevation is an important physical feature for rearing site selection by many montane North American ungulates (Barten et al. 2001, Bowyer et al 1999, and Scarpitti et al. 2007). Areas of greater terrain ruggedness are not as easy to traverse and typically decrease predation pressure. Caribou and elk have both been shown to use areas of intermediate or high levels of terrain ruggedness compared to what was available (Nellemann and Cameron 1998, Lehman et al. 2016). Areas with increased slope are also more difficult to traverse and use of these areas has been attributed as a predator avoidance mechanism. Caribou and elk have both been shown to use less-steep slopes (Barten et al. 2001, Rearden et al. 2011), contrary to desert mule deer which have been shown to use areas with steeper slopes (Fox and Krausman 1994). Increases in hiding cover can help to hide the neonate from a predator but will also aid the predator getting close to the dam and neonate(s) without being detected by the dam (Bowyer et al 1999). Therefore, a trade-off that the dam needs to make is either to have greater detectability of predators or increase the amount of hiding cover for her and her neonate(s) (Rearden et al. 2011).

Humans perhaps exert the strongest predation pressure on ungulates, and human development has also been demonstrated to influence parturition site selection. Increased public road access can increase the chance of mortality from vehicle collision and increased hunter access. Elevated traffic levels can influence the amount of perceived predation risk associated 
with roads (Litvaitis and Tash 2008, Sawyer et al. 2009). Predators are typically associated with using roadways as travel corridors, therefore, selecting areas away from roads would be a predator avoidance mechanism. Caribou, elk, and moose calving sites have been described as being away from human developments such as roads and campgrounds (Nellemann and Cameron 1998, Bowyer et al 1999, Brook 2010, Lehman et al. 2016).

Oil and natural gas development in western North America is a locally intense human disturbance that has the potential to impact ungulate resource selection. Energy development in western North America has increased over the past decade and is projected to increase by $40 \%$ over the next 20 years (Northrup and Wittemyer 2013). Mule deer have been shown to select for areas away from development (Sawyer et al. 2006, 2009 and Northrup et al. 2015). Mule deer avoided areas with active drilling rigs at a greater distance compared to areas with only producing wells which can extend up to 1-km from active drilling rigs (Sawyer et al. 2009, Northrup et al. 2015). Although oil and natural gas is known to influence resource selection of ungulates, influence during critical fawn rearing times is unknown.

For this study, I evaluated the potential impacts of oil and natural gas development on rearing resource selection of mule deer in western North Dakota (ND) and eastern Montana (MT). Mule deer declines in other regions have been attributed to low fawn survival, habitat loss/conversion, and predation (Bleich and Taylor 1998, Pojar and Bowden 2004, Sawyer et al. 2006, Lomas and Bender 2007, and Sawyer et al 2009). The role of oil and natural gas development is not well understood but may be playing an important role in the declining populations. Determining the potential effects that gas and oil development have on mule deer rearing resource selection can help inform managers on ways to mitigate potential adverse effects. 


\section{STUDY AREA}

This study occurred in western North Dakota (ND) and eastern Montana (MT) (Figure 1). Mule deer capture locations were located throughout the badlands and north to the Missouri River. Development for the extraction of oil and natural gas can be found in both study areas. However, most of the recent oil and natural gas development has occurred in ND, with a significant portion of the development in the northern region of the study area. The climate in this region is typically characterized by long cold winters and short hot summers. The average rain precipitation is 39-cm, with the majority occurring from May to September (Godfread 1994). Precipitation from snow fall is typically $30-\mathrm{cm}$. There is a collection of perennial streams that run throughout the study site, which drain into the Little Missouri River, Yellowstone River, and the Missouri River. The primary human disturbances in this study area can be attributed to ranching, farming, and infrastructure associated with gas and oil development. Row crops, hayed pastures and alfalfa planting, cattle grazing, well pads, roads, and pipelines are the main sources of human disturbance attributed to habitat loss, conversion, and fragmentation (J. L. Kolar et al., North Dakota Game and Fish, state report).

This region is characterized by highly-eroded, broken topography dominated by grassland and shrubland. Along the Little Missouri River and tributaries, silver sage (Artemisia cana) is the dominate shrub species and western wheatgrass (Agropyron smithii) is the principal grass (Godfread 1994). Cottonwood (Populus deltoids) and green ash (Fraxinus pensylvanica) are the primary tree species around water resources with buckbrush (Symphoricarpos occidentalis) as the primary understory species. Green ash is the pre-dominate tree species extending into upland draws with chokecherry (Prunus virginiana) as the primary shrub. Woody vegetation is typically located in draws and north-facing aspects and moderately steep slopes. 
The dominate woody vegetation is from various juniper species (Juniperus spp.), woods rose (Rose woodsii), and skunkbush (Rhus trilobata). South facing, moderate to steep slopes typically have sparse vegetation, if vegetated at all. These aspects are typically dominated by rabbitbrush (Chrysothamnus nauseosus), longleaf sage (Artemisia longifolia), and greasewood (Sarcobatus vermiculatus) (Godfread 1994). Grassland species distribution in this region is dependent on the soil type, moisture, and salinity. The most commonly found grasses are needle-and-thread (Stipa comate) and blue grama (Bouteloua gracilis). Little bluestem (Andropogon scoparius) is commonly found on moderate to steep slopes with a north to east aspect. Western wheatgrass, blue grama, and buffalo grass (Buchloe dactyloide) are found on gentle slopes with finer soil types. Forbs typically found in this area include buckwheat (Eriogonum multiceps), gumbo lily (Oenothera caespitosa), butte candle (Cryptantha celosoides), red mallow (Sphaeralcea coccinea), and prickly pear (Opuntia plycantha).

\section{METHODS}

\section{Capture and Handling}

We captured female mule deer via helicopter net-gunning in February 2013, December 2013, February 2014, and December 2014. We captured and collared 101 adults and 106 juveniles in ND and 30 adults and 43 juveniles in MT (Table 1). Female mule deer were fitted with satellite global positioning system (GPS) radio collars (G2110L Iridium and G2110L Iridium; Advanced Telemetry System Inc. [ATS], Isanti, MN). The collars were programmed to collect a location every 5 hours. Location data was transmitted every 4 days via satellite, which allowed for the data to be collected without disturbing the deer. The collars were programed to activate a 'mortality mode' if no activity was detected for $>6$ hours. Once in mortality mode, 
the collar would transmit a real-time mortality notification and hourly coordinates until either activity was detected or the collar was retrieved.

\section{Parturition Date Estimation}

I evaluated rearing resource selection for doe during the 8 weeks following parturition. I estimated date of parturition for all adult female mule deer using the GPS collar location data collected from 01 May - 15 July for each year. I selected this date range because the average date of parturition for mule deer at this latitude occurs in early June (Jensen 1988, Bowyer et al. 1991, Lomas and Bender 2007, Long et al. 2009, Freeman et al. 2014). I used an individual based model (IBM) developed by DeMars et al. (2013) to infer female mule deer parturition status. This model first evaluates the mean step length and determines behavioral break points to determine if the doe gave birth or not. Then using the behavioral break points the method estimates the date of parturition (Figure 2). Visual inspection indicated this method produced reasonable estimates of parturition dates, as all estimated dates were within the range of known parturition dates reported in the literature (Figure 3).

\section{Rearing Resource and Covariate Estimation}

After determining the temporal period over which I evaluated resource selection, I then obtained a collection of used and available resource locations. Used locations were the GPS locations obtained over the temporal rearing period. I determined available locations by first determining the area around the used location available for selection by the dam. I determined the available area using Durner et al. (2009) available habitat radius method. This method determines the habitat that would be available for selection by the dam given the distance a mule deer could have travel between consecutive GPS fixes. The typical habitat radius was 480- 
meters, which varied for each year. I then generated 4 random points within the available habitat buffer centered around each used point (Figure 4). The choice sets contained 1 used location and 4 locations that were available for selection.

I collected spatial covariates for each used and available point. One covariate I recorded was cover type. Cover type was collected using the United States Department of Agriculture (USDA) National Agricultural Statistical Services (NASS) 30-m United States Cropland layer (USDA NASS 2013-2016). The levels for cover type were condensed into 7 broad categories: barren, crop, grass, hay, legume, shrub, and wood. Northness was another spatial covariate I used which was measured by taking the cosine of the aspect. I first calculated the aspect from a Digital Elevation Model (DEM) layer using the Spatial Analyst toolbox in ArcInfo 10.5. Distance to nearest water resource was measured using line and polygon shapefiles obtained from the North Dakota GIS Hub Data Portal. I used both a stream\river and lakelpond layers to determine available water resources on the landscape. I calculated distance to nearest water resource using the gDistance function within the 'rgeos' packing version $0.3-25$ (Bivand et al. 2017) in program R version 3.4.2 (R Core Team 2017).

Next, I collected spatial covariates of topography associated with hiding cover and predator avoidance. I collected elevation for each used and available point. Elevation was collected using a 30-m DEM layer. Next, I calculated slope and terrain ruggedness for each used and available location. Slope was calculated from the DEM layer using the Spatial Analyst toolbox in ArcInfo 10.5. I calculated a terrain ruggedness index using equations provided in Sappington et al. (2007) with values ranging from 0 to 1 , where greater values indicated greater ruggedness. 
I then collected covariates associated with human disturbance for each used and available point. I collected oil and natural gas development covariates from the North Dakota Industrial Commission, Oil and Gas Division, ArcIMS viewer (NDIC 2017). I classified well pads into two categories: drilling rig or active well pad. A well pad was classified as a drilling rig for any period of time when a well was being actively drilled on the well pad. The well pad then transitioned to an active well pad after the drilling infrastructure has been removed from the site and there is at least one producing well on the well pad. Development covariates included distance from each used and available point to the nearest active drilling rig and well pad. I calculated distance to nearest drilling rig and well pad using the gDistance function within the 'rgeos’ packing version 0.3-25 (Bivand et al. 2017) in program R. I also collected distance to nearest primarylsecondary road for each used and available point. I obtained road data from the North Dakota Department of Transportation (NDDOT 2016) and manually digitized missing roads from 2015 aerial imagery at a 1:5,000 scale. From this layer, I calculated distance from each used and available point to the nearest primarylsecondary road using the gDistance function within the 'rgeos' packing in program $\mathrm{R}$.

\section{Statistical Methods}

I modeled female mule deer rearing resource selection with discrete choice models (Cooper and Millspaugh 1999). I modeled the probability of selecting a used location from within each choice set as a function of the covariates described above. The first step in model selection was to determine which form (i.e., linear, quadratic, and pseudo-threshold) was most appropriate for each covariate. I determined this by fitting univariate models (only 1 variable at a time) with each of the 3 forms. Each covariate form was evaluated using Akaike Information Criterion (AIC) and the form with the lowest AIC was used in final model construction. 
After determining which forms to include in the model (Table 2), I grouped covariates into 4 covariate groups: topographic, oil and natural gas, road and water, and vegetation. Within each covariate group, I first fit 'full' models that included all covariates within that group. To obtain a more parsimonious model, I then fit a 'reduced' model that contained only covariates that had an absolute value of the Wald test statistic $>1.64$ (Table 3). Once I found the most parsimonious model for each covariate group I then fit 11 models representing all combination of covariate groups and ranked model performance using AIC (Table 4).

\section{RESULTS}

Rearing resource selection was determined using 129 adult female mule deer from 2013 2016. Rearing resource selection was calculated from 69,433 choice sets (representing 69,433 used locations and 277,732 available locations). The model including the effects of topography, oil and natural gas development, road and water, and vegetation out performed all other models (Table 4) with no model selection uncertainty (i.e., relative weight of top model $\sim 1$ ). I, therefore, base all inference on this top model.

I found an effect of drilling rigs on adult female mule deer rearing resource selection when mule deer were in close proximity to a drilling rig. For example, when I assumed a deer can select points within $1-\mathrm{km}$ of an active drilling rig, a deer is $17 \%$ more likely to select a point 1-km from an active drilling rig than 0.3-km from a rig (Figure 5). Given the pseudo-threshold nature of the response, the effect of proximity from a drilling rig was local. For example, when a site was 30.3-km away from a drilling rig compared to 31-km away from a drilling rig the relative probability of selection remained constant. Mule deer rearing resource selection was weakly related to the distance from a well pad. For example, when we assume a deer can select 
points within 1-km from a well pad, a deer is $1.2 \%$ more likely to select a point 1 -km from a well pad than 0.3-km from a well pad (Figure 6).

I found a relationship between roads and adult female mule deer rearing resource selection when mule deer were in close proximity to a road. For example, when I assumed a deer can select points within 1-km from a road, a deer is 5\% more likely to select a point 1-km from a road than 0.3-km from a road (Figure 7). Given the pseudo-threshold nature of the response, the effect of proximity of roads was local. For example, when a site was 5-km away from a road compared to 6-km from a road the relative probability of selection remained constant at approximately fifty percent.

I found a relationship between distance to nearest water body (i.e. streams or pondsllakes) and adult female mule deer rearing resource selection when mule deer were in close proximity to a water resource. For example, when we assume a deer can select points within 1$\mathrm{km}$ from a water resource, a deer is $1.3 \%$ more likely to select a point $0.2-\mathrm{km}$ from a water resource compared to 0.5-km from a water resource (Figure 8).

I found a clear effect of topographic variables and adult female mule deer rearing resource selection. Mule deer were most likely to select intermediate values of elevation, slope, and terrain ruggedness. For each, relative probability of use was greatest at 751-m, 17 degrees, and a terrain ruggedness index of 0.85 , respectively (Figure 9).

Rearing resource selection was related to vegetation type. Adult female mule deer were more likely to use wooded and shrub cover types and least likely to use crop, legume, and barren areas for rearing young (Figure 10). 


\section{DISCUSSION}

I found evidence to suggest that oil and natural gas development influences adult female mule deer rearing resource selection. Mule deer selected rearing sites that were located further from oil and natural gas active drilling rigs than randomly available. This suggests that parturient mule deer may perceive some risk associated with the drilling phase of oil and natural gas development. There is also a greater amount of human disturbance around these areas which has the potential to increase the amount of perceived risk with these areas (Sawyer et al. 2009). There is also more vehicle traffic visiting the drilling rig and with increased traffic levels mule deer could perceive a greater amount of risk. Avoidance of development during the rearing season for mule deer has yet to be explicitly document in the literature; however, avoidance of development has been documented for caribou during the calf rearing season (Nellemann and Cameron 1998). Avoidance of oil and natural gas development during other seasons has been documented for mule deer (Sawyer et al. 2006, 2009, Northrup et al. 2015). The distance at which mule deer avoided disturbance for these studies varied temporally and ranged anywhere from 0 - 1000-meters.

I found evidence to suggest that roads have a modest effect on selection of rearing sites. Mule deer selected for areas further from roads than what was available for selection. Selection for areas away from roads would coincide with trying to reduce perceived risk. Vehicle traffic has been shown to increase perceived risk associated with roads (Sawyer et al. 2009). My finding is consistent with other studies that found mule deer, caribou, elk, and moose selecting birth and post-parturition locations located further from roads (Nellemann and Cameron 1998, Bowyer et al. 1999, Long et al. 2009, Brook 2010, Lehman et al. 2016). 
Mule deer selected for wooded or shrub areas greater than any other vegetation type for rearing habitat. Selection for wooded and shrub areas could provide the female with more forage availability to help offset the increase in energy needs brought on by lactation. Wooded and shrub areas could also provide more concealment cover for hiding neonate(s) from predators. The dominate shrub type found throughout the study area is silver sage (Godfread 1994). Silver sage would offer mule deer a source of forage, however due to the thick nature in which silver sage grows it would also provide an excellent source of concealment cover for neonates. Upland draws and riparian areas is where wooded vegetation is typically found. Wooded areas around riparian areas will contain cottonwood as the dominate canopy species with green ash as the predominant understory species (Godfread 1994). Upland wooded draws typically contain green ash as the dominant canopy species with chokecherry as the predominant understory (Godfread 1994), both species providing the dam with a source of forage. Wooded areas throughout the study area follow the drainage from runoff which allows for added soil moisture needed for tree growth. Therefore, selection of wooded areas could provide the dam with additional water resource after a rainfall event. Long et al. (2009) also found that mule deer selected for wooded areas more during the week of parturition and weeks following parturition than grassland types.

Female mule deer selected for areas located closer to water resources. The on-set of lactation increases the demand for water; therefore, selection for areas located near water resource is not surprising. Selection for areas located closer to water resource(s) could also be related to selection for forage and not as a predator avoidance mechanism. Riparian areas throughout both study areas were typically where woody vegetation was found on the landscape (Godfred 1994). Although predators will often use riparian habitat as both travel corridors and areas to search for prey (Bowyer et al 1999), we observed higher selection for these areas. My 
findings are consistent with other studies that found mule deer, moose, and elk selecting birth sites closer to water (Leptich and Gilbert 1986, Long et al. 2009, McGraw et al. 2011, Lehman et al. 2016).

In relation to topography covariates, females selected for areas of intermediate elevation, slope, and terrain ruggedness. By selecting for intermediate elevation females would be spacing away from predators (Poole et al. 2007). Selection for intermediate elevations could also act as an early predator detection mechanism (Bowyer et al. 1999 and Rearden et al. 2011). Also, intermediate elevation would allow mule deer to have better predator avoidance but lower amounts of vegetation compared to lower elevations. Intermediate terrain ruggedness and slope could allow the neonate to have lower predation pressure related to these topographic features. These types of complex terrain features can also facilitate the neonate escaping predation. Predators will typically search for prey in areas that are easy to traverse, such as areas of gentle slope and lower terrain ruggedness (Fox and Krausman 1994 and Farmer et al. 2006). The selection for intermediate slope and terrain ruggedness is consistent with other mule deer studies examining rearing resource selection (Fox and Krausman 1994 and Long et al. 2009). Selection for rearing sites located in intermediate rugged terrain ruggedness and elevations could also be a way to avoid human disturbance. In areas with greater terrain complexity it could act as a buffer to disturbance from well pads and roads.

\section{MANAGEMENT IMPLICATIONS}

My results suggest that rearing resource selection could be influenced by oil and natural gas development on the landscape. Mule deer are selecting rearing sites located further away from active drilling rigs, well pads, and roads. The movement away from oil and natural gas infrastructure in this area is consistent with resource selection in other seasons within the same 
population (Kolar et al. 2017). Human disturbance from oil and natural gas infrastructure may be acting as a source of indirect habitat loss with a footprint expanding beyond the well pad and roadways. One way to reduce human impacts on the landscape associated with oil and natural gas development would be to consolidate the number of well pads on the landscape. To achieve this, the use of horizontal drilling will allow for multiple wells on one well pad. Another way to reduce human impacts on the landscape would be to develop new wells on pre-existing roads. This would reduce the amount of roads on the landscape and would reduce habitat fragmentation and loss which would potentially help mule deer as well as other wildlife species. Limiting the timing of active drilling rigs on the landscape to post fawn rearing could be beneficial for the dam and neonate during this sensitive time for survival. During the fawn rearing season, the dam is on a strict energy budget and increased energy expenditures and stress from development could be lethal (Skelly 2018). Development of a suitability map for determining critical mule deer rearing habitat could be one way to mitigate loss by establishing well pads in areas designated as low probability of use for fawn rearing. Consolidating oil and natural gas development, as suggested, may also minimize the development footprint on the landscape. 


\section{FIGURES}

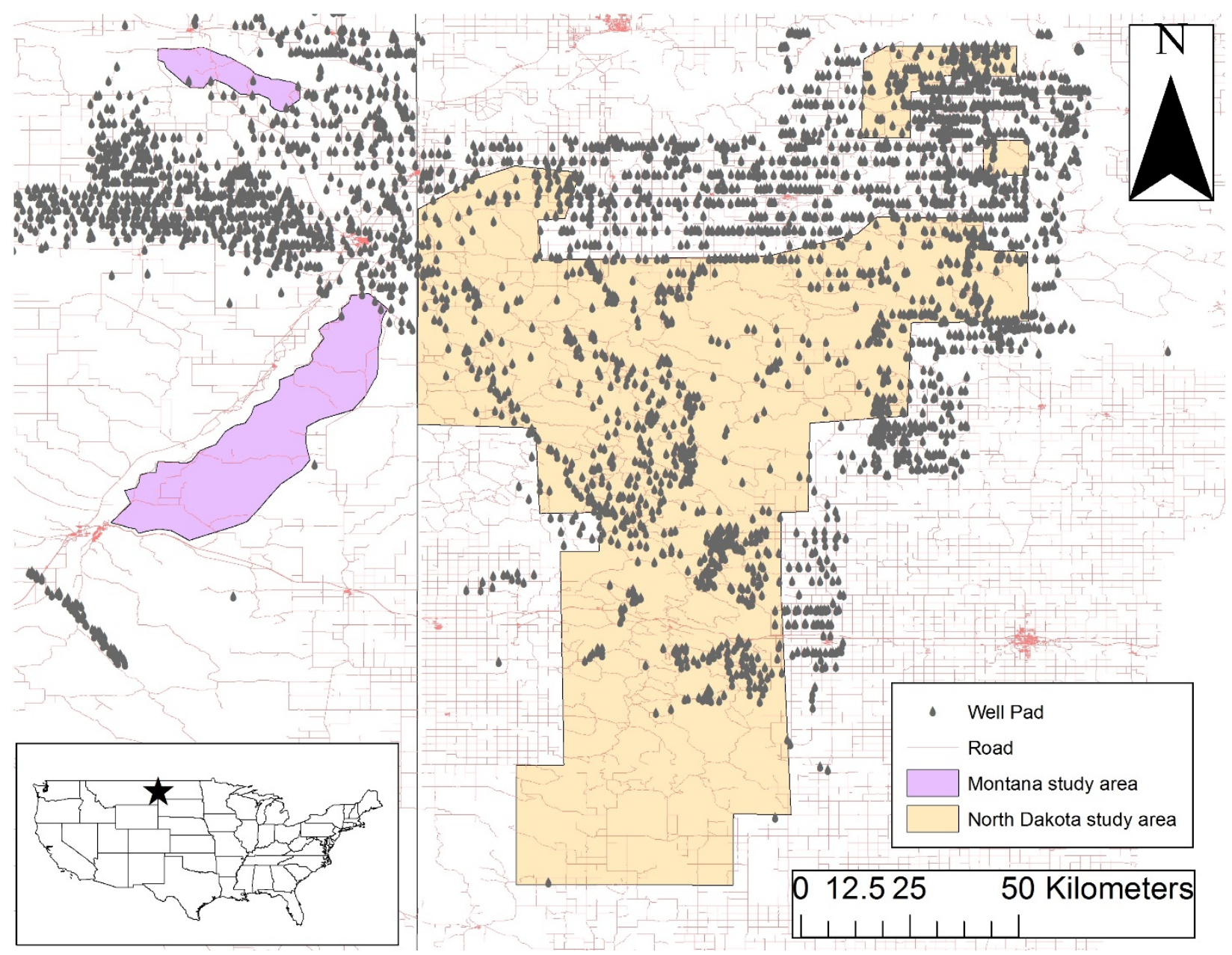

Figure 1. Study areas for estimating mule deer rearing resource selection in western North

Dakota and eastern Montana, USA, between 2013 - 2016. 


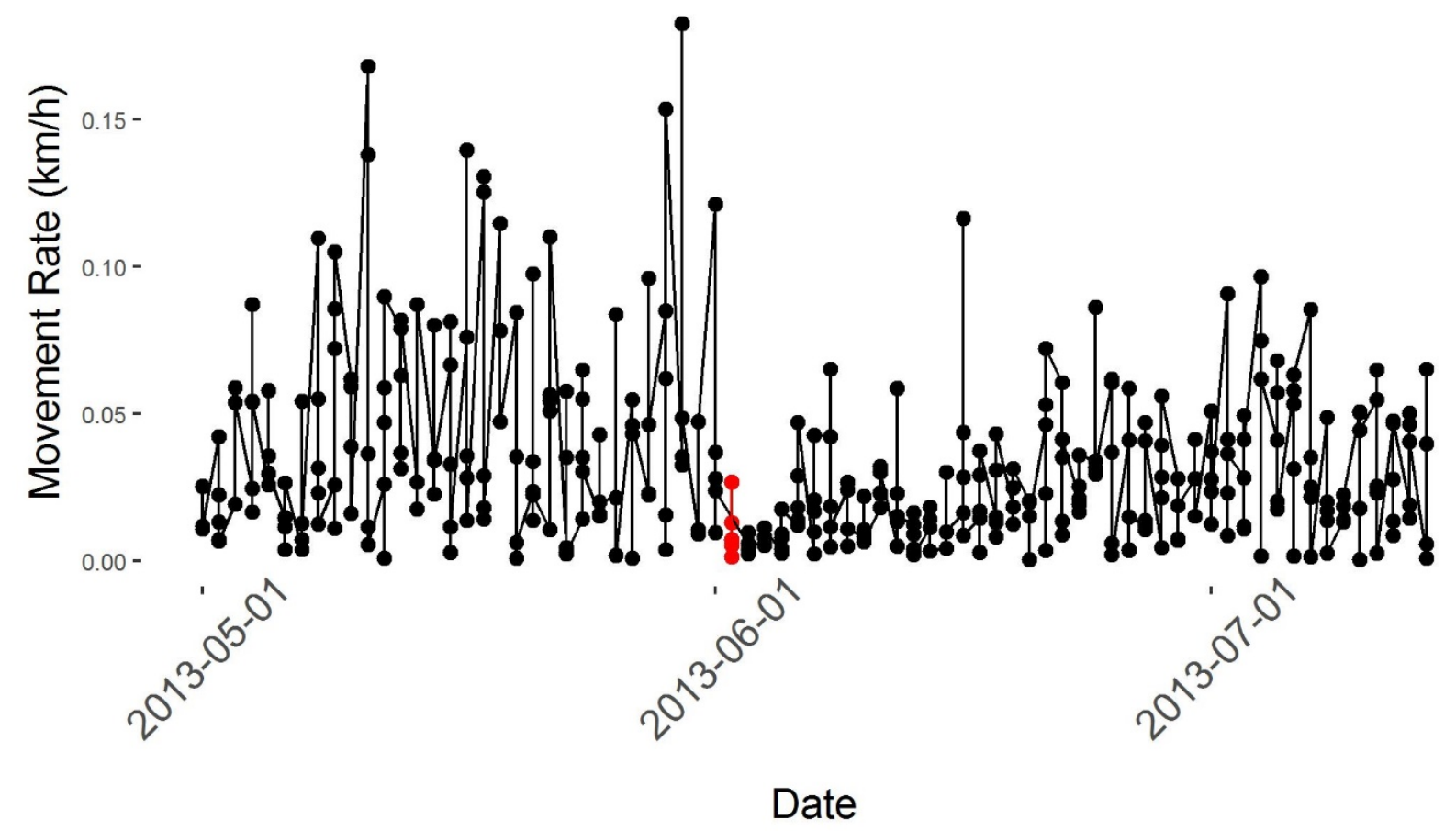

Figure 2. Movement rate determined by GPS locations collected every 5 hours for an adult mule deer doe in western North Dakota from 01 May through 15 July 2013. Estimated date of parturition by the DeMars et al. (2013) method was 02 June (blue dots). 


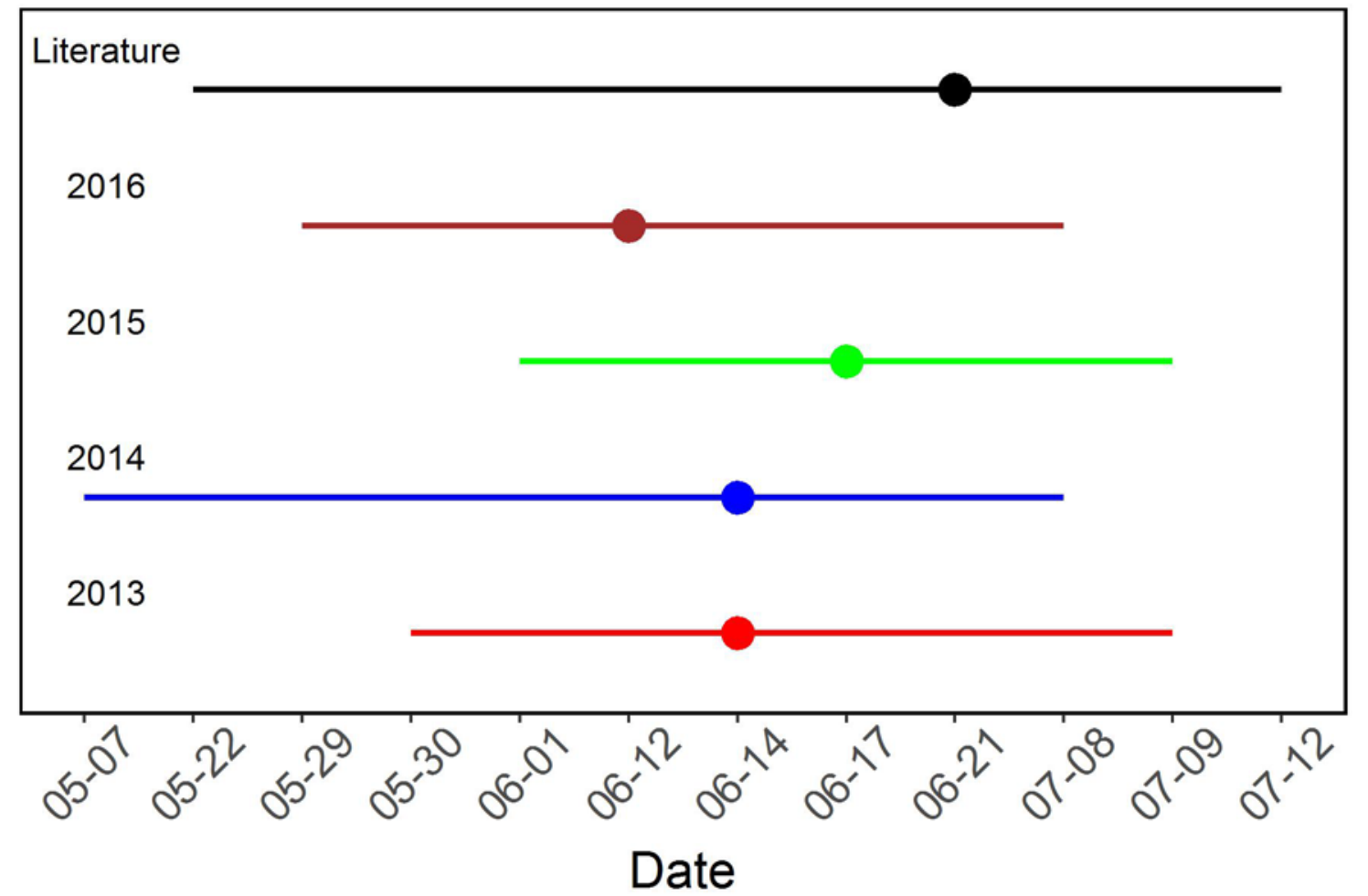

Figure 3. Estimated mean (point) and range of (horizontal lines) date of birth for adult female mule deer in western North Dakota and eastern Montana, USA, 2013 - 2016, using the DeMars et al. (2013) method compared to estimated date of parturition reported in the literature (black dot). 


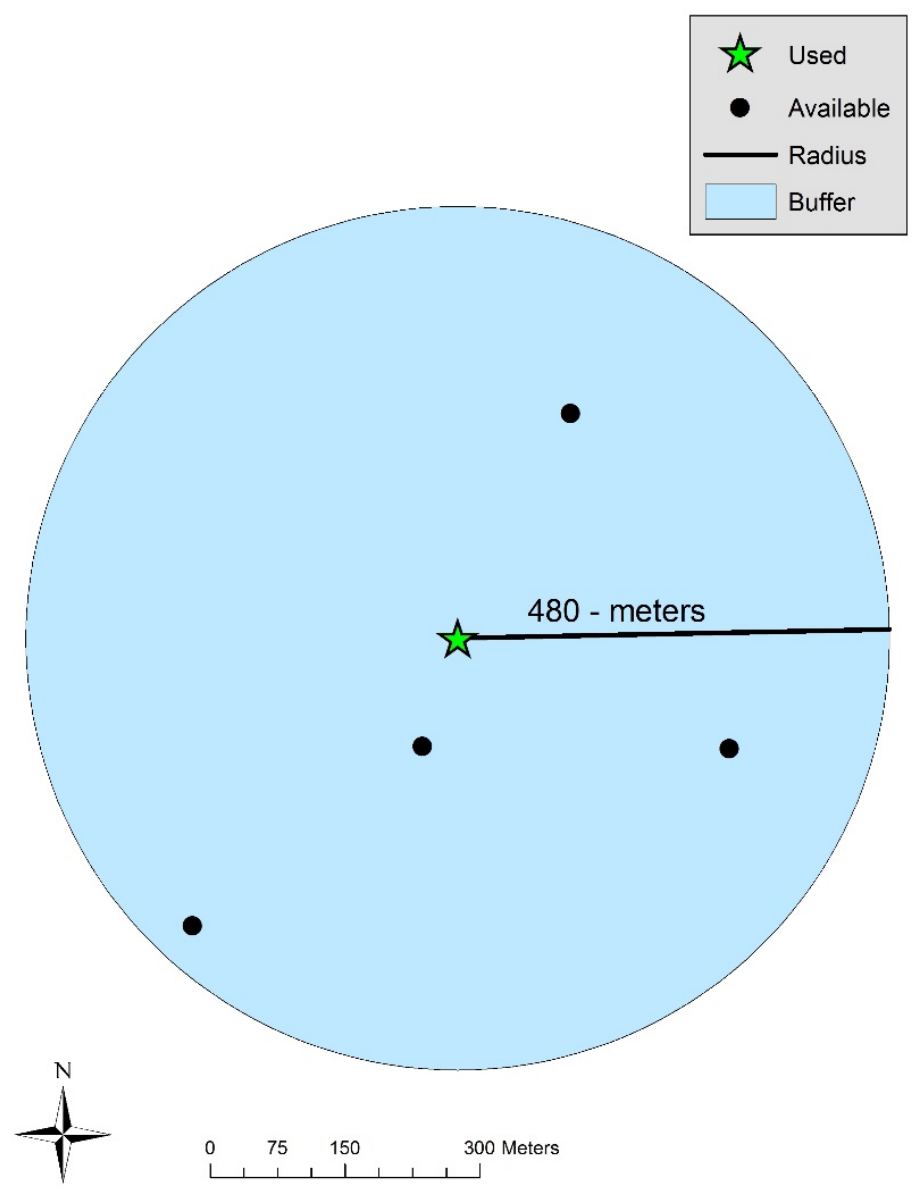

Figure 4. Estimated available habitat radius method described by Durner et al. (2009) for generation available units for selection. The used unit (green star) is the GPS location collected and 4 available units (black dots) randomly generate within the buffer of available habitat for selection. 


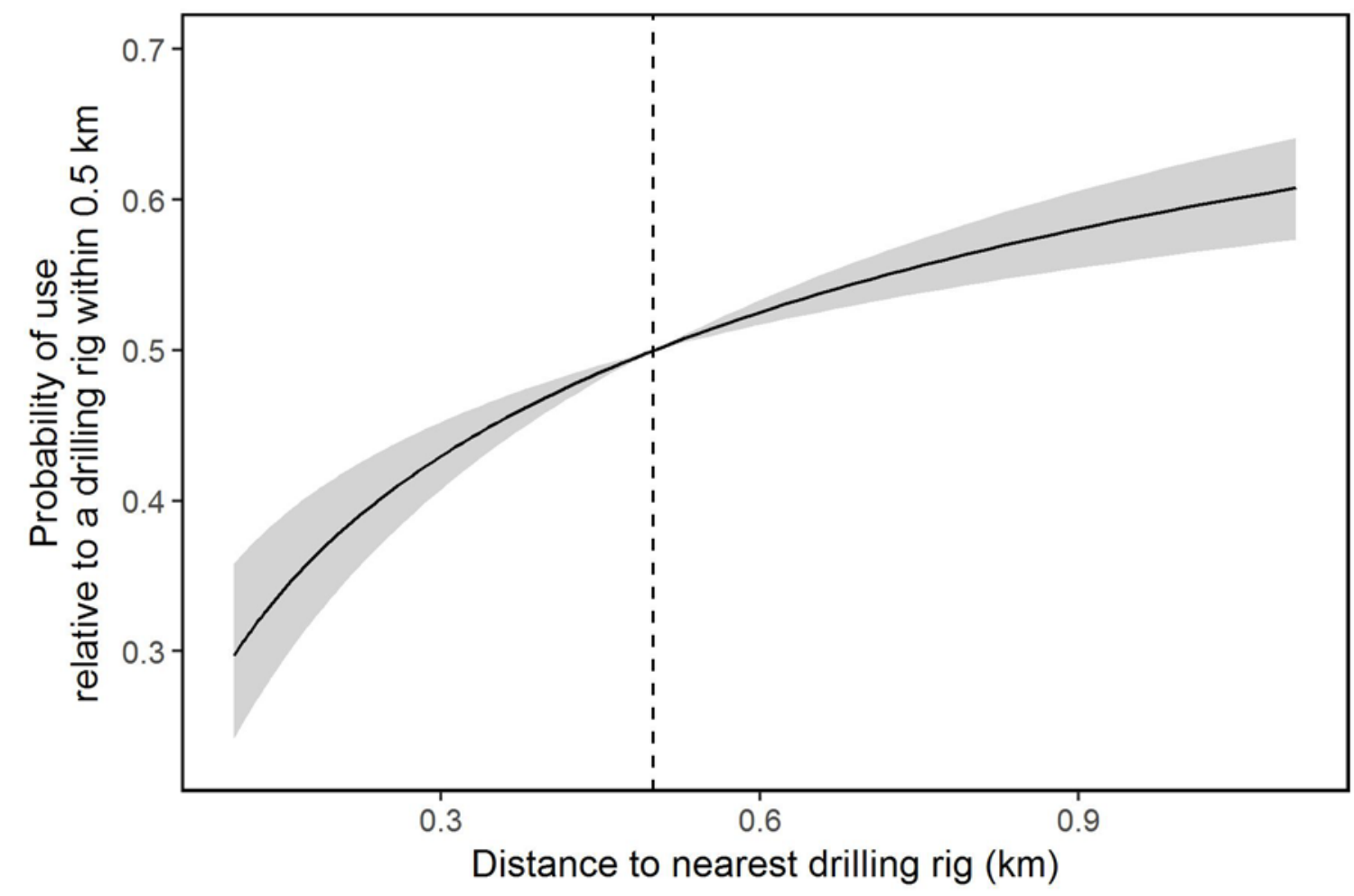

Figure 5. Probability of an adult female mule deer within 8 weeks of parturition using a site as a function of distance to nearest oil and natural gas drilling rig, relative to a site located 0.5-km. This figure assumes all choices are 0 - 1-km from a drilling rig because the effect of distance to drilling rig is purely local, and diminishes as distance from drilling rig increases. Black lines represent the probability of selection as a rearing site and the shaded area represent the $95 \%$ confidence intervals. 


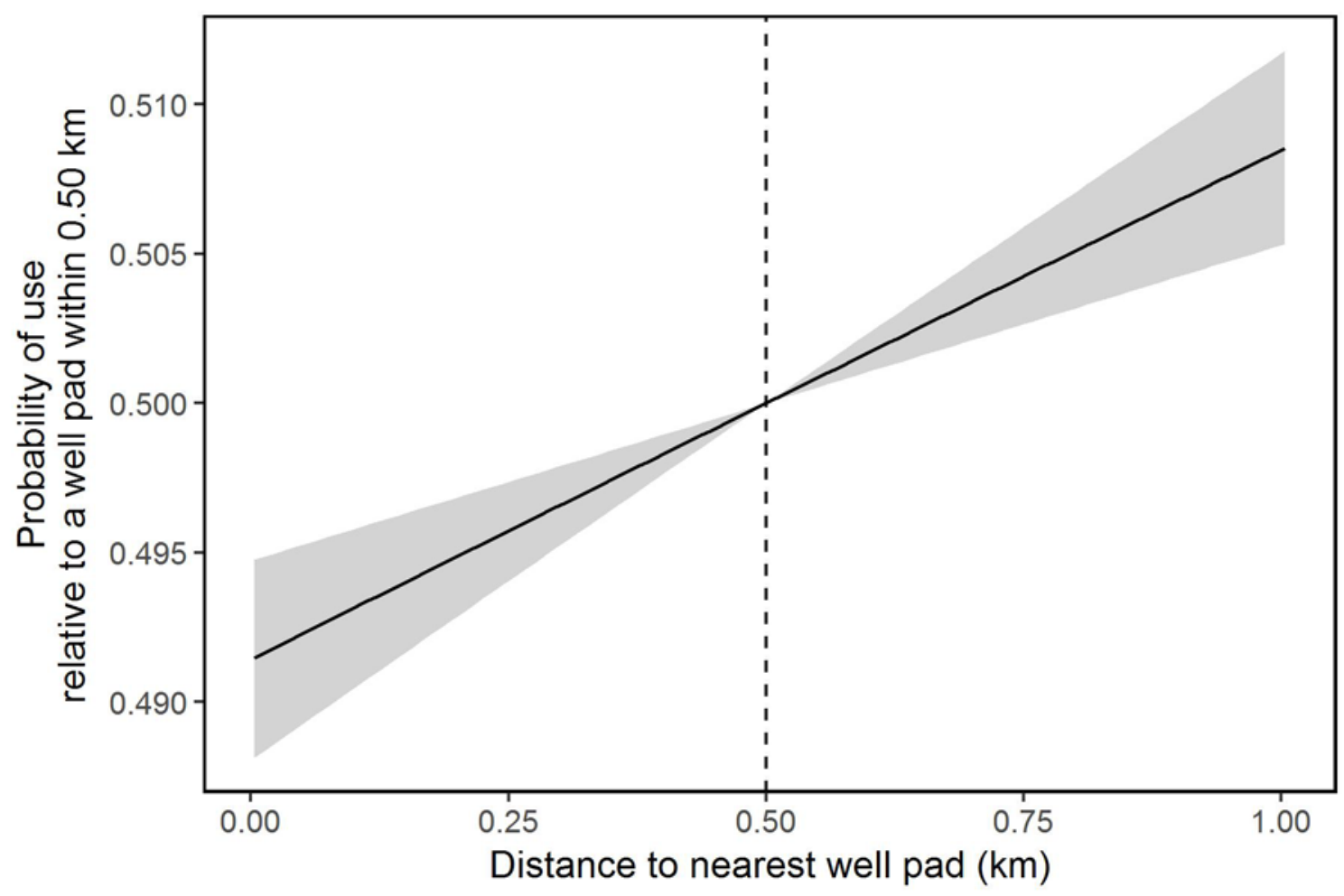

Figure 6. Probability of an adult female mule deer within 8 weeks of parturition using a site as a function of distance to nearest oil and natural gas well pad, relative to a site located 0.5-km. This figure assumes all choices are $0-1-\mathrm{km}$ from a well pad. Black lines represent the probability of selection as a rearing site and the shaded area represent the $95 \%$ confidence intervals. 


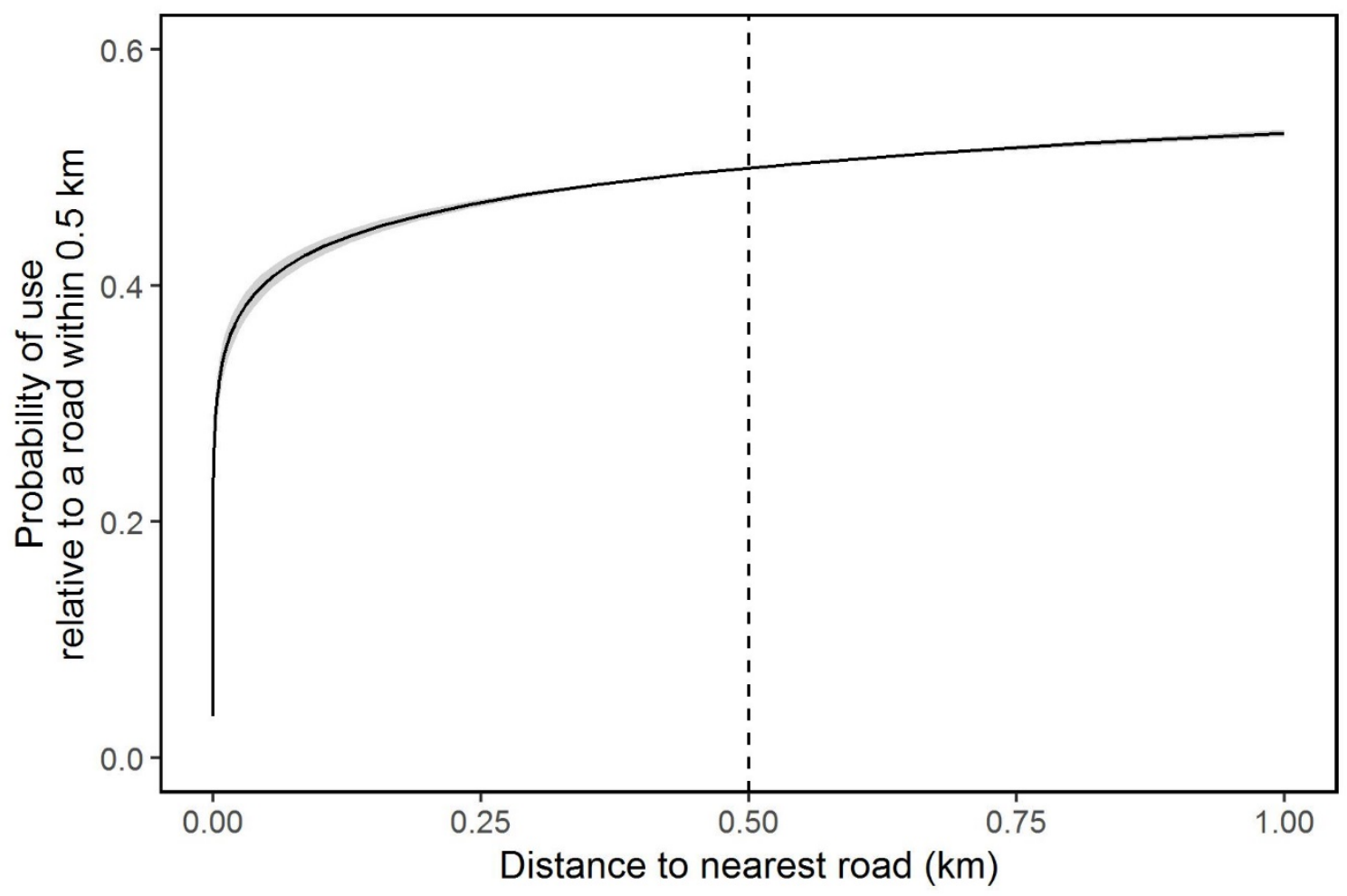

Figure 7. Probability of an adult female mule deer within 8 weeks of parturition using a site as a function of distance to nearest road, relative to a site located $0.5-\mathrm{km}$. This figure assumes all choices are $0-1-\mathrm{km}$ from a road because the effect of distance to primarylsecondary road is purely local, and diminishes as distance from primary/secondary road increase. Black lines represent the probability of selection as a rearing site and the shaded area represent the $95 \%$ confidence intervals. 


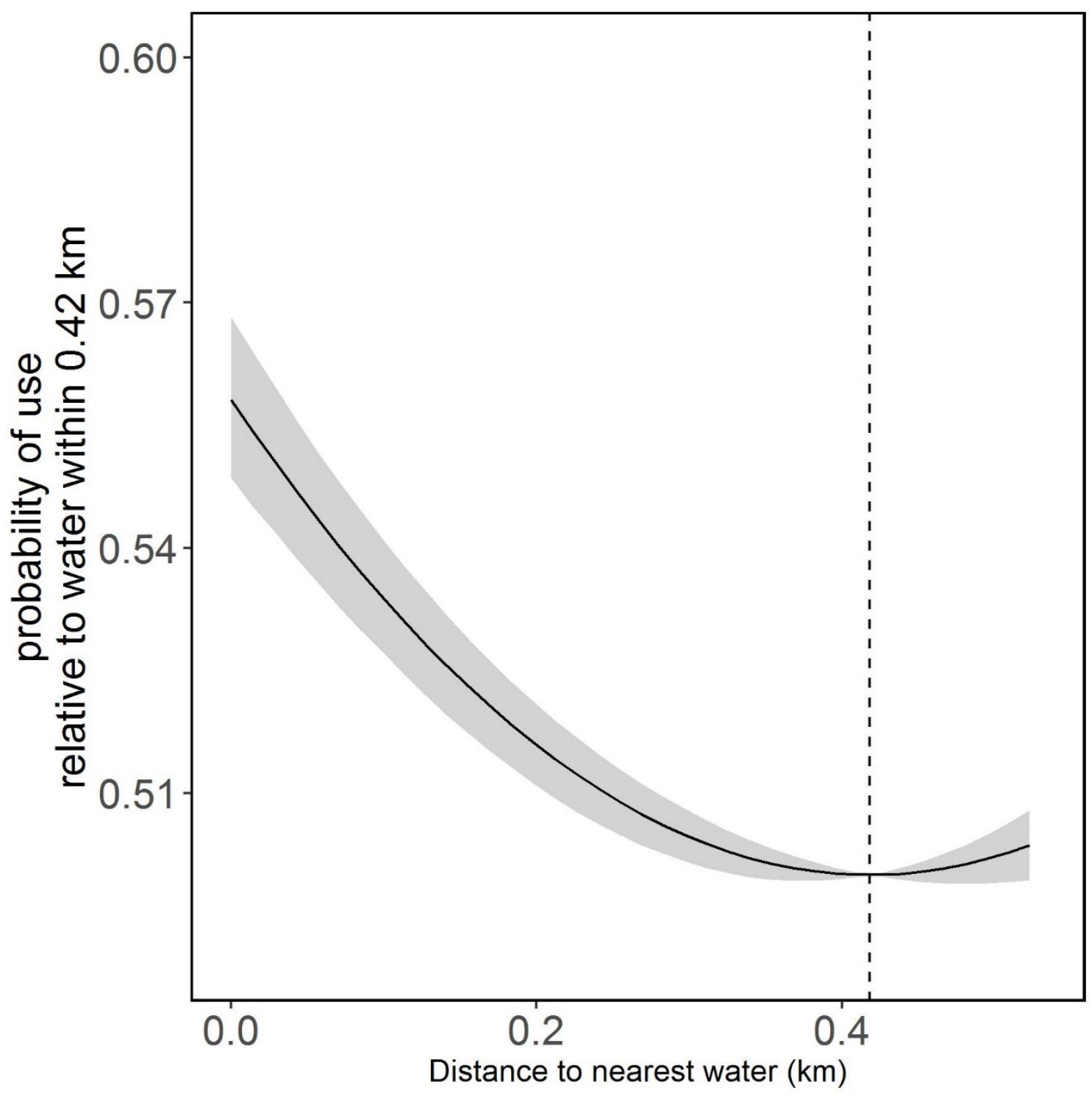

Figure 8. Probability of an adult female mule deer within 8 weeks of parturition using a site as a function of distance to nearest water, with the lowest probability of use $0.42-\mathrm{km}$ away. Black lines represent the probability of selection as a rearing site and the shaded area represent the $95 \%$ confidence intervals. The vertical dotted line represents the distance from a water resource with the minima probability of use for like choice sets. 

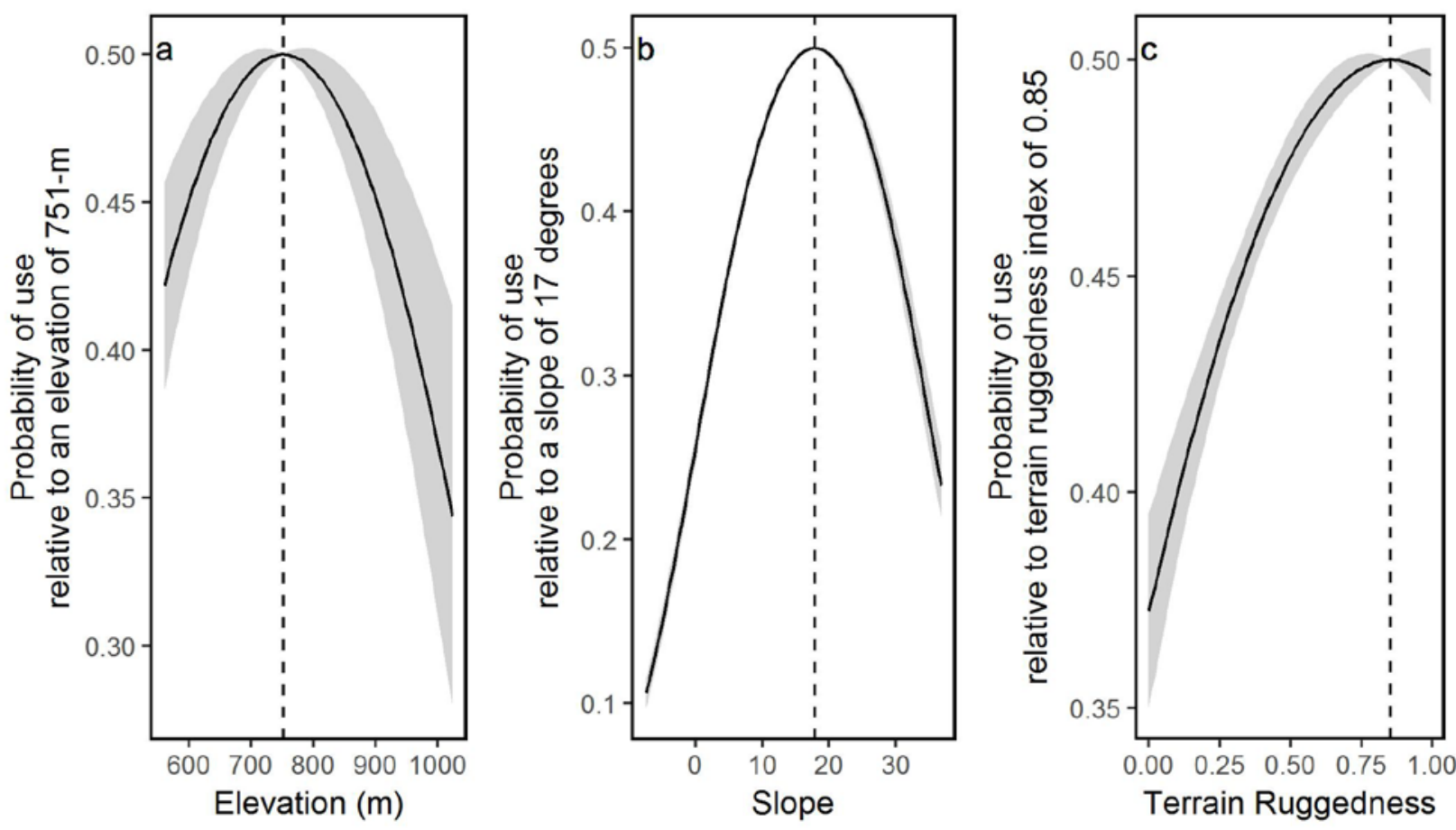

Figure 9. Probability of an adult female mule deer within 8 weeks of parturition using a site as a function of elevation, slope, and terrain ruggedness, with the greatest probability of use occurring at 751-m, 17 degrees, and 0.85, respectively. Black lines represent the probability of selection as a rearing site and the shaded area represent the $95 \%$ confidence intervals. The vertical dotted line represents the covariate value of highest probability of use. 


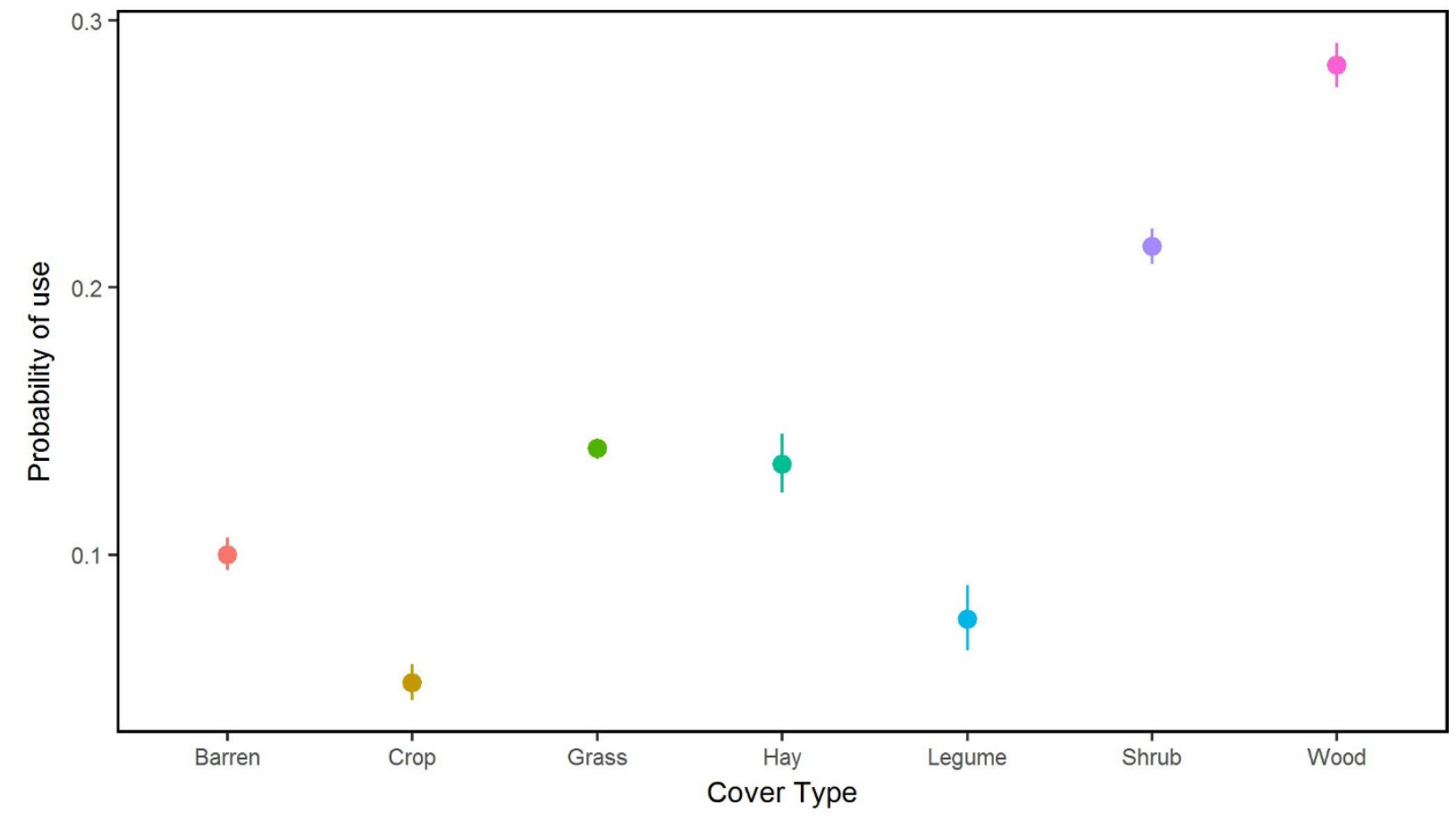

Figure 10. Probability of an adult female mule deer within 8 weeks of parturition using a site as a function of cover type. This plot assumes a choice set with all cover type equally available, and all other variable constant across cover types. Points represent the probability of use as a rearing site and the 95\% confidence intervals. 


\section{TABLES}

Table 1. Capture summary for female mule deer captured in western North Dakota and eastern Montana via helicopter net-gunning and fitted with satellite global positioning system (GPS) telemeter collars programmed to collect a location every 5 hours in winter of 2012, 2013, and 2014.

\begin{tabular}{ccccccc}
\hline & \multicolumn{3}{c}{ North Dakota } & \multicolumn{3}{c}{ Montana } \\
\hline Capture Year & Adult & Juveniles & Total & Adult & Juveniles & Total \\
$2012^{*}$ & 60 & 30 & 90 & - & - & - \\
2013 & 16 & 30 & 46 & 20 & 20 & 40 \\
2014 & 25 & 46 & 71 & 10 & 23 & 33 \\
Total & 101 & 106 & 207 & 30 & 43 & 73 \\
\hline
\end{tabular}

*The 2012 captures were delayed until February, 2013. 
Table 2. Summary of covariates and the form used in estimating adult female mule deer rearing resource selection using discrete choice models.

\begin{tabular}{lcc}
\hline Covariate Group & Parameter & Form \\
\hline Topography & Elevation & Quadratic \\
& Slope & Quadratic \\
Terrain ruggedness & Quadratic \\
Northness & Pseudo-threshold \\
Development & Drilling rig distance * State & Pseudo-threshold \\
Well pad distance & Quadratic \\
Road and Water & Road distance & Pseudo-threshold \\
Water distance & Quadratic \\
Barren & Linear \\
Crop & Linear \\
Grass & Linear \\
Hay & Linear \\
Legume & Linear \\
Shrub & Linear \\
\hline
\end{tabular}


Table 3. Model selection results for adult female mule deer rearing resource selection covariate groups using discrete choice models. Bold AIC values denote the model that was used in final model construction.

\begin{tabular}{|c|c|c|c|}
\hline Group & Model & Variables & AIC \\
\hline \multirow[t]{4}{*}{ Topography } & Full & Elevation, Elevation ${ }^{2}$, Slope, Slope ${ }^{2}$, Terrain & 216462.7 \\
\hline & & ruggedness, Terrain ruggedness ${ }^{2}$, Northness & \\
\hline & Reduced & Elevation, Elevation², Slope, Slope ${ }^{2}$, Terrain & 216461.2 \\
\hline & & ruggedness, Terrain ruggedness ${ }^{2}$, & \\
\hline \multirow[t]{2}{*}{ Development } & Full & Rig Distance * State, Well distance, Well distance ${ }^{2}$ & 175185.2 \\
\hline & Reduced & Well distance, Well distance ${ }^{2}$ & 175231.7 \\
\hline \multirow[t]{2}{*}{ Road and Water } & Full & Road distance, water distance, water distance ${ }^{2}$ & 220766.0 \\
\hline & Reduced & NA & - \\
\hline \multirow[t]{2}{*}{ Vegetation } & Full & Barren, Crop, Grass, Hay, Legume, Shrub, Wood & 215320.8 \\
\hline & Reduced & NA & - \\
\hline
\end{tabular}


Table 4. Adult female mule deer rearing resource models for western North Dakota and eastern Montana, USA, 2013-2016, using 69,433 choice sets (69,433 used units and 277,732 available units), ranked by lowest AIC.

\begin{tabular}{|c|c|c|c|c|}
\hline Model & $\mathbf{K}$ & $\Delta \mathbf{A I C}$ & AIC & Model Weight \\
\hline Global & 18 & 0.0000 & 165184.4 & 1.00 \\
\hline Landform and Development and Vegetation & 15 & 517.1264 & 165701.5 & 0.00 \\
\hline Development and Road and Water and Vegetation & 12 & 3038.0265 & 168222.4 & 0.00 \\
\hline Landform and Development and Road and Water & 12 & 3697.1362 & 168881.5 & 0.00 \\
\hline Development and Vegetation & 9 & 3939.9627 & 169124.3 & 0.00 \\
\hline Landform and Development & 9 & 4451.9663 & 169636.3 & 0.00 \\
\hline Development and Road and Water & 6 & 8333.8692 & 173518.2 & 0.00 \\
\hline Development Full & 3 & 10000.7786 & 175185.2 & 0.00 \\
\hline Landform and Road and Water and Vegetation & 15 & 44895.5616 & 210079.9 & 0.00 \\
\hline Landform and Vegetation & 12 & 45904.8812 & 211089.3 & 0.00 \\
\hline Road and Water and Vegetation & 9 & 48556.9058 & 213741.3 & 0.00 \\
\hline Landform and Road and Water & 9 & 49891.8466 & 215076.2 & 0.00 \\
\hline Vegetation & 6 & 50136.4192 & 215320.8 & 0.00 \\
\hline Landform Reduced & 6 & 51276.8543 & 216461.2 & 0.00 \\
\hline Road and Water Full & 3 & 55581.5964 & 220766.0 & 0.00 \\
\hline
\end{tabular}




\section{CONCLUSION}

I found evidence to suggest that oil and natural gas development influences survival probability of mule deer in western North Dakota. Mine is the first to document a direct, albeit weak, link between oil and natural gas exploration and survival probability of mule deer. Mule deer coming out of winter are typically on strict energy budgets and increased movement or stress associated with development could be lethal (Bradshaw et al. 1997). I also found evidence to suggest that roads have a weak effect on mule deer survival probability. Mule deer located closer to roads could be experiencing decreased survival related to increased vigilance and perceived predation risk leading to increased flight energy expenditures. Increased vigilance can decrease the amount of time spent on biological needs such as foraging and resting (Bradshaw et al. 1997).

I also found evidence to suggest that oil and natural gas development influences adult female mule deer rearing resource selection. Mule deer selected rearing sites that were located further from oil and natural gas drilling rigs than randomly available. This suggests that parturient mule deer may perceive some risk associated with the drilling phase of oil and natural gas development. The areas around drilling rigs are more recently disturbed, therefore, predators such as coyotes could be using these patch areas for prey searching. There is also a greater amount of human disturbance around these areas which has the potential to increase the amount of perceived risk with these areas (Sawyer et al. 2009). There is also more vehicle traffic visiting the drilling rig and with increased traffic levels mule deer could perceive a greater amount of risk. Avoidance of development during the rearing season for mule deer has yet to be explicitly document in the literature; however, avoidance of development has been documented for caribou during the calf rearing season (Nellemann and Cameron 1998). Avoidance of oil and natural gas 
development during other seasons has been documented for mule deer (Sawyer et al. 2006, 2009, Northrup et al. 2015).

I have demonstrated that active drilling rigs on the landscape may have an effect on mule deer survival and rearing resource selection. Limiting activing drilling times to during the late summer and autumn when mule deer are not energetically stressed could reduce the impact for mule deer on strict energy budgets during the late winter and spring. Consolidating infrastructure may also be a possible way to reduce the amount of impact on mule deer and other species (Sawyer et al. 2006, 2009, Northrup et al. 2016, Skelly 2018). One way to consolidate infrastructure may be the use of horizontal drilling, which will allow for the consolidation of multiple wells to a single well pad (Clark 1949, Sawyer et al. 2009). While this will likely increase the size of the well pad, it will limit the amount of well pads on the landscape. I also observed moderate effects of roads on mule deer survival and rearing resource selection. Another way to consolidate oil and natural gas associated infrastructure would be to place well pads on pre-existing roads, therefore, reducing the amount of roads on the landscape (Northrup et al. 2015). Also, limiting the construction of new roads will lower the amount of habitat loss either directly or indirectly due to avoidance.

Pre-development planning should identify areas with low mule deer density / low probability of mule deer use. Future development should be concentrated in areas identified as low density / use by mule deer. Well pads could then implement horizontal drilling and extract oil or natural gas from areas identified as high mule deer density / high probability of use while reduce surface impacts (Sawyer et al. 2009). 


\section{LITERATURE CITED}

Barbknecht, A.E., S.W. Faribanks, J.D. Rogerson, E.J. Maichak, B.M. Scurlock, and L.L. Meadows. 2011. Elk parturition site selection at local and landscape scales. The Journal of Wildlife Management. 75:646-654.

Barten, N.L., T.R. Bowyer, and K.J. Jenkins. 2001. Habitat use by female caribou: Tradeoffs associated with parturition. The Journal of Wildlife Management. 65:77-92.

Beckmann, J.P., K. Murray, R.G. Seidler, and J. Berger. 2012. Human-mediated shifts in animal habitat us: Sequential changes in pronghorn use of natural gas fields in Greater Yellowstone. Biological Conservation. 147: 222-233.

Beckmann, J.P., S.H. Olson, R.G. Seidler, and J. Berger. 2016. Sub-lethal effects of energy development on a migratory mammal - The enigma of North American pronghorn. Global Ecology and Conservation. 6:36-47.

Bishop, C.J., J.W. Unsworth, and E.O. Garton. 2005. Mule deer survival among adjacent populations in southwest Idaho. The Journal of Wildlife Management. 69:311-321.

Bivand, R., C. Rundel, E. Pebesma, R. Stuetz, and K.O. Hufthammer. 2017. Interface to Geometry Engine - Open Source (GEOS). Package verison 03-22. https://r-forge.rproject.org/projects/rgeos/.

Bleich, V.C., and T.J. Taylor. 1998. Survivorship and cause-specific mortality in five populations of mule deer. The Great Basin Naturalist. 58:265-272.

Bowyer, T.R., 1991. Timing of parturition and lactation in southern mule deer. Journal of Mammalogy. 72:138-145.

Bowyer, T.R., V. Van Ballenberghe, J.G. Kie, and J.A.K. Maier. 1999. Birth-site selection by Alaskan moose: Maternal strategies for coping with a risky environment. Journal of Mammalogy. 80:1070-1083. 
Bradshaw, C.J., S. Boutin, and D.M. Hebert. 1997. Effects of petroleum exploration on woodland caribou in Northeastern Alberta. The Journal of Wildlife Management. 61:1127-1133.

Brodie, J., H. Johnson, M. Mitchell, P. Zager, K. Proffitt, M. Hebblewhite, M. Kauffman, B. Johnson, J. Bissonette, C. Bishop, J. Gude, J. Herbert, K. Hersey, M. Hurly, P.M. Lukacs, S. McCorquodale, E. Mclntire, J. Nowak, H. Sawyer, D. Smith, and P.J. White. 2013. Relative influence of human harvest, carnivores, and weather on adult female elk survival across western North America. Journal of Applied Ecology. 50:295-305.

Brook, R.K., 2010. Habitat selection by parturient elk (Cervus elaphus) in agricultural and forested landscapes. Canadian Journal of Zoology. 88:968-976.

Carnes. J. C., 2009. Mule deer population ecology and chronic wasting disease study. Final Report. Montana Fish Wildlife \& Parks, Miles City, Montana, USA.

Christie, K.S., W.F. Jensen, S.E. Nielsen, and M.S. Boyce. 2015. Long-term changes in pronghorn abundance index linked to climate and oil development in North Dakota. Biological Conservation. 192:445-453.

Ciuti, S., W.F. Jensen, S.E. Nielsen, and M.S. Boyce. 2015. Predicting mule deer recruitment from climate oscillations for harvest management on the Northern Great Plains. The Journal of Wildlife Management. 79:1226-1238.

Clark, J.B. 1949. A hydraulic process for increasing the productivity of wells. Journal of Petroleum. 2510:1-8.

Cooper, A.B. and J.J. Millspaugh. 1999. The application of discrete choice models to wildlife resource selection studies. Ecology. 80:566-575. 
Copeland, H.E., K.E. Doherty, D.E. Naugle, A. Pocewicz, and J.M. Kiesecker. 2009. Mapping oil and gas development potential in the US intermountain west and estimating impacts to species. PLoS ONE. 4:e7400.

Davis, M.L., P.A. Stephens, P. Kjellander. 2016. Beyond climate envelope projections: Roe deer survival and environmental change. The Journal of Wildlife Management. 80:452-464.

DeMars, C.A., M. Auger-Methe, U.E. Schlagel, and S. Boutin. 2013. Inferring parturition and neonatal survival from movement patterns of female ungulates: a case study using woodland caribou. Ecology and Evolution. 3:4149-4160.

Dodge, S., G. Bohrer, R. Weinzierl, S.C. Davidson, R. Kays, D. Douglas, S. Cruz, J. Han, D. Brandes, and M. Wikelski. 2013. The environmental-data automated track annotation (Env-DATA) system: Linking animal tracks with environmental data: Movement Ecology. 3:1-14.

Doherty, K.E., D.E. Naugle, B.L. Walker, and J.M. Gramham. 2006. Greater sage-grouse habitat selection and energy development. The Journal of Wildlife Management. 72:187-195.

Duong, T. 2017. Kernel Smoothing. Package version 1.11.0. http://www.mvstat.net/tduong.

Durner, G.M., D.C. Douglas, R.M. Nielson, S.C. Amstrup, T.L. McDonald, I. Stirling, M. Mauritzen, E.W. Born, O. Wiig, E. DeWeaver, M.C. Serreze, S.E. Belikov, M.M. Holland, J. Maslanik, J. Aars, D.A. Bailey, and A.E. Derocher. 2009. Predicting 21stcentury polar bear habitat distribution from global climate models. Ecological Monographs. 79:25-58.

Dyer, S.J., J.P. O’Neill, S.M. Wasel, and S. Boutin. Avoidance of industrial development by woodland caribou. 2001. The Journal of Wildlife Management. 65:531-542. 
Farmer, C.J., D.K. Person, and T.R. Bowyer. 2006. Risk factors and mortality of black-tailed deer in a managed forest landscape. The Journal of Wildlife Management. 70:1403-1415.

Fox, K.B. and P.R. Krausman. 1994. Fawning habitat of desert mule deer. The Southwestern Naturalist. 39:269-275.

Freeman, E.D., R.T. Larsen, M.E. Peterson, C.R. Anderson JR., K.R. Hersey, and B.R. McMillian. 2014. Effects of male-biased harvest on mule deer: Implications for rates of pregnancy, synchrony, and timing of parturition. Wildlife Society Bulletin. 38:806-811.

Gilbert, M.M., and A.D. Chalfoun. 2011. Energy development affects populations of sagebrush songbirds in Wyoming. The Journal of Wildlife Management. 75:816-824.

Godfread, C. 1994. The Vegetation of the Little Missouri Badlands of North Dakota. Leafy Spurge Strategic Planning Workshop. 17-24.

Gratson, M.W., and C.L. Whitman. 2000. Road closure and density and success of elk hunters in Idaho. Wildlife Society Bulletin. 28:302-310.

Grovenburg, T.W., R.W. Klaver, and J.A. Jenks. 2012. Survival of white-tailed deer fawns in the grasslands of the northern great plains. The Journal of Wildlife Management. 76:944-956.

Holloran, M.J., R.C. Kaiser, and W.A. Hubert. 2010. Yearling greater sage-grouse response to energy development in Wyoming. The Journal of Wildlife Management. 74:65-72.

Hovick, T.J., R.D. Elmore, D.K. Dahlgren, S.D. Fuhlendorf, and D.M. Engle. 2014. Evidence of negative effects of anthropogenic structures on wildlife: a review of grouse survival and behavior. Journal of Applied Ecology 51:1680-1689.

Hurley, M.A., M. Hebblewhite, J.M. Gaillard, S. Dray, K.A. Taylor, W.K. Smith, P. Zager, C. Bonenfant. 2014. Functional analysis of Normalized Difference Vegetation Index curves 
reveals overwinter mule deer survival is driven by both spring and autumn phenology. Philosophical Transactions of the Royal Society B 369:20130196.

Jackson, R.D. and A.R. Huete. 1991. Interpreting vegetation indices. Preventive Veterinary Medicine. 11:185-200.

Jensen, W.F. 1988. Summer and fall ecology of mule deer in the North Dakota badlands. Dissertation. University of North Dakota. Grand Forks, USA.

Jones, N.F., L. Pejchar, and J.M. Kiesecker. 2015. The energy footprint: how oil, natural gas, and wind energy affect land for biodiversity and the flow of ecosystem services. BioScience 65:290-301.

Kolar, J.L., J.J. Millspaugh, B.A. Stillings, C.P. Hansen, C. Chitwood, C.T. Rota. 2017. Potential effects of oil and gas energy development on mule deer in western North Dakota. North Dakota Game and Fish State Report.

Langley, M.A. and D.H. Pletscher. 1994. Calving areas of moose in Northwestern Montana and Southeastern British Columbia. Alces. 30:127-135.

Lehman, C.P., M.A. Rumble, C.T. Rota, B.J. Bird, D.J. Fogarty, and J.J. Millspaugh. 2016. Elk resource selection at parturition sites, Black Hills, South Dakota. The Journal of Wildlife Management. 80:465-478.

Lendrum, P.E., C.R. Anderson Jr., K.L. Monteith, J.A. Jenks, and T.R. Bowyer. 2013. Migrating mule deer: effects of anthropogenically altered landscapes. PLOS one 8:1-10.

Leptich, D.J. and J.R. Gilbert. 1986. Characteristics of moose calving sites in Northern Maine as determined by multivariate analysis: A preliminary investigation. Alces. 22:69-81.

Litvaitis, J.A. and J.P. Tash. 2008. An approach toward understanding wildlife-vehicle collisions. Environmental Management. 42:688-697. 
Lomas, L.A. and L.C. Bender. 2007. Survival and cause-specific mortality of neonatal mule deer fawns, North-central New Mexico. The Journal of Wildlife Management. 71:884-894.

Long, R.A., J.G. Kie, T.R. Bowyer, and M.A. Hurley. 2009. Resource selection and movement by female mule deer Odocoileus hermionus: Effects of reproductive stage. Wildlife Biology 15:288-298.

Lukacs, P.M., G.C. White, B.E. Watkins, R.H. Kahn, B.A. Banulis, D.J. Finley, A.A. Holland, J.A. Martens, and J. Vayhinger. 2008. Separating components of variation in survival of mule deer in Colorado. The Journal of Wildlife Management. 73:817-826.

Mazerolle, M.J. 2017. Model Selection and Multimodel Interence Based on (Q)AIC(c). Package version 2.1-1. https://cran.r-project.org/web/packages/AICcmodavg/AICcmodavg.pdf.

McDonald, R.I., J. Fargione, J. Kiesecker, W.M. Miller, and J. Powell. 2009. Energy Sprawl or energy efficiency: Climate policy impacts on natural habitat for the United States of America. PLoS ONE. 4: e6802.

McGraw, A.M., R. Moen, and M. Schrage. 2011. Characteristics of post-parturition areas of moose in Northern Minnesota. Alces. 47:113-124.

McGraw, A.M., J. Terry, and R. Moen. 2014. Pre-parturition movement patterns and birth site characteristics of moose in Northeast Minnesota. Alces. 50:93-103.

Meisingset, E.L., L.E. Loe, O. Brekkum, B.Van Moorter, and A. Mysterud. 2013. Red deer habitat selection and movements in relation to roads. The Journal of Wildlife Management. 77:181-191.

Mutter, M., D.C. Pavlacky jr., N.J. Van Lanen, and R. Grenyer. 2015. Evaluating the impact of gas extraction infrastructure on the occupancy of sagebrush-obligate songbirds. Ecological Applications 25:1175-1186. 
Nellemann, C. and R.D. Cameron. 1998. Cumulative impacts of an evolving oil-field complex on the distribution of calving caribou. Canadian Journal of Zoology. 76:1425-1430.

Nelson, M.E. and D.L. Mech. 1986. Relationship between snow depth and gray wolf predation on white-tailed deer. The Journal of Wildlife Management. 50:471-474.

North Dakota GIS. 2017. GIS hub data portal. URL: https://apps.nd.gov/hubdataportal/srv/en/main.home

North Dakota Industrial Commission. 2017. Oil and Gas: ArcIMS Viewer. https://www.dmr.nd.gov/OaGIMS/viewer.htm

Northrup, J.M. and G. Wittemyer. 2013. Characterizing the impacts of emerging energy development on wildlife, with an eye towards mitigation. Ecological Letters. 16:112-125.

Northrup, J.M., C.R. Anderson Jr., and G. Wittemyer. 2015. Quantifying spatial habitat loss from hydrocarbon development through assessing habitat selection patterns of mule deer. Global Change Biology. 21:3961-3970.

Northrup, J.M., C.R. Anderson Jr., and G. Wittemyer. 2016. Environmental dynamics and anthropogenic development alter philopatry and space-use in a North American cervid. Diversity and Distribution. 22:547-557.

Pac, D.F. and G.C. White. 2007. Survival and cause-specific mortality of male mule deer under different hunting regulations in the Bridge Mountains, Montana. The Journal of Wildlife Management. 71:816-827.

Pojar, T.M. and D.C. Bowden. 2004. Neonatal mule deer fawn survival in west-central Colorado. The Journal of Wildlife Management. 68:550-560.

Poole, K.G., R. Serrouya, and K. Stuart-Smith. 2007. Moose calving strategies in interior montane ecosystems. Journal of Mammalogy. 88:139-150. 
R Core Team. 2016. R: A language and environment for statistical computing. R Foundation for Statistical Computing. Vienna, Austria. URL https://www.R-project.org/.

Rearden, S.N., R.G. Anthony, B.K. Johnson, and J.L. Rachlow. 2011. Birth-site selection and predation risk of rocky mountain elk. Journal of Mammalogy. 92.1118-1126.

Ryan, R.W., D.D. Gustine, and K. Joly. 2014. Evaluating potential effects of an industrial road on winter habitat of caribou in North-Central Alaska. Artic Institute of North America. 67:472-482.

Sappington, J.M., K.M. Longshore, and D.B. Thompson. 2007. Quantifying landscape ruggedness for animal habitat analysis: a case study using bighorn sheep in the Mojave Desert. Journal of Wildlife Management. 71:1419-1426.

Sawyer, H., R.M. Nielson, F. Lindzey, and L.L. McDonald. 2006. Winter habitat selection of mule deer before and during development of a natural gas field. The Journal of Wildlife Management. 70:396-403.

Sawyer, H., M.J. Kauffman, and R.M. Nielson. 2009. Influence of well pad activity on winter habitat selection patterns of mule deer. The Journal of Wildlife Management. 73:10521061.

Scarpitti, D.L., P.J. Pekins, and A.R. Musante. 2007. Characteristics of neonatal moose habitat in northern New Hampshire. Alces. 43:29-38.

Vore, J.M., and E.M. Schmidt. 2001. Movements of female elk during calving season in Northwest Montana. Wildlife Society Bulletin. 29:720-725.

Walker, B.L., D.E. Naugle, and K.E. Doherty. 2007. Greater sage-grouse population response to energy development and habitat loss. The Journal of Wildlife Management 71:26442654. 
Wallmo, O.C. 1981. Mule and black-tailed deer of North America USA. University of Nebraska Press, Lincoln, Nebraska.

Webb, S.L., M.R. Dzialak, S.M. Harju, L.D. Hayden-wing, and J.B. Winstead. 2011. Effects of human activity on space use and movement patterns of female elk. Wildlife Society Bulletin. 35:261-269.

White, G.C., R.A. Garrott, R.M. Bartmann, L.H. Carpenter, and W.A. Alldredge. 1987. Survival of mule deer in Northwest Colorado. The Journal of Wildlife Management. 51:852-859.

Wikelski, M., and R. Kays. 2017. Movebank: archive, analysis and sharing of animal movement data. Hosted by the Max Planck Institute for Ornithology. www.movebank.org. accessed on 02 June. 2017. 